\title{
O que está em jogo teologicamente no debate sobre a ordenação de homens casados?
}

\author{
What is theologically at stake in the priesterly ordination of married man \\ debate?
}

Antônio José Almeida*

\begin{abstract}
Resumo
Entre as questões a serem tratadas pelo Sínodo Especial para a Amazônia (Roma, 2019), está a situação de dezenas de milhares de comunidades que, na região amazônica, não têm acesso regular à celebração da eucaristia por falta de presbíteros. Em axioma famoso, Henri de Lubac (1896-1991), aprofundando o tema da relação Eucaristia-Igreja na literatura eclesiástica do primeiro milênio cristão, dizia que " $A$ Igreja faz a Eucaristia, e a Eucaristia faz a Igreja". Muitas comunidades se reúnem para celebrar a Palavra de Deus, e sabemos que a Palavra está na origem da Igreja: a Igreja é, sem dúvida, "criatura da Palavra". Falta a essas comunidades, porém, a celebração frequente (preferivelmente dominical) da Eucaristia, pois é a celebração da eucaristia que "faz a Igreja". Dado que a Igreja celebra a eucaristia ("a Igreja faz a eucaristia") sempre sob a presidência de um sacerdote (bispo ou presbítero), e estes, na Amazônia, faltam cronicamente, o autor sugere que se revejam algumas condições para a ordenação, entre elas o próprio celibato, para que a Igreja na Amazônia possa, com ministros ordenados próprios, chegar à plenitude da sua constituição eclesial e missionária.
\end{abstract}

Palavras-chave: Eucaristia; Igreja; presbítero; acesso ao ministério; comunidade.

\begin{abstract}
Between the topics to be addressed by the Amazon Special Synod (Rome, 2019) is the condition of thousands of communities that, in the Amazon region, do not have access to weekly Eucharist due to the lack of priests. In a famous axiom, Henri de Lubac (1896-1991), deepening the Eucharist-Church relation theme in the ecclesiastic literature during the first Christian millennium, says that "The Church makes the Eucharist, and the Eucharist makes the Church". Several communities gather in order to celebrate the Word of God, and it is known that the Word is in the origin of the Church: the Church is certainly a "Creation of the Word". Those communities lack, however, the frequent celebration preferably at Sundays - of Eucharist, for it is the celebration of Eucharist that "makes the Church". Since the Church celebrates Eucharist ("Church makes the Eucharist") always under the presidency of a priest or bishop and these, in the Amazon, lack chronically, the author suggests that some ordination conditions should be reviewed, including celibacy, in order to the Church in Amazon be able, with its ordained ministers, reach its full ecclesiastic and missionary constitution.
\end{abstract}

Keywords: Eucharisty; Church; presbyter; access to ministry; community.

Artigo submetido em 11 de outubro de 2018 e aprovado em 05 de maio de 2019.

* Doutor em Teologia. Professor da PUC-PR. País de origem: Brasil. E-mail: ajacatedral@uol.com.br 


\section{Introdução}

Aproximando-se o Sínodo Especial para a Amazônia, a ser celebrado em Roma do dia 6 a 27 de outubro de 2019, entre tantas questões vitais para a região e para o futuro da própria humanidade, não podem ficar de lado as questões relativas à vida e à missão da Igreja, como, aliás, está expresso no próprio tema definido pelo Papa Francisco: “Amazônia: novos caminhos para a Igreja e para uma ecologia integral”.

A parte relativa à Igreja se encontra especialmente na terceira parte (o “agir”) do Documento Preparatório. No processo de pensar essa Igreja, "sonhamos com os pés fincados na terra de nossos ancestrais e com os olhos abertos pensamos como será essa Igreja a partir da vivência da diversidade cultural dos povos. Os novos caminhos terão uma incidência nos ministérios, na liturgia e na teologia (teologia indígena)." (SÍNODO PARA A AMAZÔNIA, 2018, n. 82).

E um dos pontos principais a ser escutado será o lamento "de milhares dessas comunidades privadas da Eucaristia dominical por longos períodos" (DOCUMENTO DE APARECIDA 100e). (SÍNODO PARA A AMAZÔNIA, 2018, n. 64). Mais adiante, se lê:

Nesse sentido, o Vaticano II nos lembra que todo o povo de Deus participa do sacerdócio de Cristo, embora distinguindo sacerdócio comum do sacerdócio ministerial (LG 10). Partindo daí, urge avaliar e repensar os ministérios que hoje são necessários para responder aos objetivos de «uma Igreja com rosto amazônico e uma Igreja com rosto indígena». [...] É preciso repensar novos caminhos para que o Povo de Deus tenha melhor e frequente acesso à Eucaristia, centro da vida cristã. (SÍNODO PARA A AMAZÔNIA, 2018, n. 81).

A religiosidade popular, deixada pelos missionários e missionárias no período colonial, é um tesouro precioso (DOCUMENTO DE APARECIDA 258267), mas não é suficiente. As celebrações da Palavra (DOCUMENTO DE APARECIDA 253), além de ter um valor em si, têm ajudado milhares de comunidades a se alimentar da Palavra de Deus (EVANGELII GAUDIUM 174-175; 
DOCUMENTO DE APARECIDA 247-249), mas também não são suficientes nem muito menos substituem a celebração da eucaristia (DOCUMENTO DE APARECIDA 253). Em muitas comunidades, graças à reserva eucarística, pode-se até mesmo comungar, mas uma coisa é comungar, outra é celebrar consciente, ativa e frutuosamente a Eucaristia no Dia do Senhor, fazendo memória de sua Ressurreição e participando de seu mistério (DOCUMENTO DE APARECIDA 250252). Religiosidade popular, Palavra de Deus e celebração da Eucaristia são chamadas a interagir e a fecundar-se reciprocamente e a tornarem-se lugares diferenciados, ao alcance de todos, mas não alternativos, de encontro com o Cristo vivo! Diz o Papa Francisco:

A Palavra de Deus ouvida e celebrada, sobretudo na Eucaristia, alimenta e reforça interiormente os cristãos e torna-os capazes de um autêntico testemunho evangélico na vida diária. Superamos já a velha contraposição entre Palavra e Sacramento: a Palavra proclamada, viva e eficaz, prepara a recepção do Sacramento e, no Sacramento, essa Palavra alcança a sua máxima eficácia. (EVANGELII GAUDIUM 174).

A situação de dezenas de milhares de comunidades espalhadas pelos imensos territórios amazônicos sem celebração dominical (ou ao menos relativamente frequente) da Eucaristia exige uma abertura intelectual, uma conversão pastoral e uma reflexão teológica que nos ajudem a ver em profundidade a gravidade pastoral, espiritual e teológica desta situação absolutamente anômala e a buscar soluções pastoralmente viáveis e coerentes com a fé eclesial. Sabemos que a Igreja - povo de Deus, corpo de Cristo, tempo do Espírito, sacramento de comunhão - se constrói pelo anúncio da Palavra e pela celebração dos Sacramentos, particularmente a Eucaristia, ambos realizados pela comunidade cristã, dotada de graças a carismas e ministérios vários e diferentes. Por isso, a reflexão a seguir vai se concentrar nestes três elementos: a Palavra (a Palavra cria a Igreja), a Eucaristia (a Eucaristia faz a Igreja); a Assembleia litúrgica (a Igreja faz a Eucaristia). 


\section{A Igreja é construída pela palavra "creatura verbi"}

"O que era desde o princípio, o que ouvimos, o que vimos com nossos olhos, o que contemplamos, e o que nossas mãos apalparam da Palavra da Vida - porque a Vida manifestou-se: nós a vimos e dela damos testemunho e vos anunciamos esta Vida Eterna, que estava voltada para o Pai e que nos apareceu - o que vimos e ouvimos vo-lo anunciamos para que estejais em comunhão conosco. E a nossa comunhão é com o Pai e com o seu Filho Jesus Cristo" (1Jo 1,1-3). A Igreja nasce, portanto, do testemunho e do anúncio da Palavra da Vida. Aquilo que o Apóstolo viu e experimentou é anunciado "para que também vós estejais em comunhão conosco. E a nossa comunhão é comunhão com o Pai e com o seu Filho Jesus Cristo".

$\mathrm{Na}$ origem da Igreja - e de toda comunidade eclesial - se encontra o anúncio em torno ao qual "se cria uma comunhão, porque a experiência de Cristo que o anunciante fez é comunicada aos outros, e todos se veem, em virtude do anúncio, a viver do mesmo Cristo." (DIANICH, 1981, p. 58)

A Igreja, com efeito, se constitui pela fé dos seus membros: de um lado, a fé das testemunhas originárias do evento Cristo que o anunciam a outros; do outro, a fé daqueles que acolhem os portadores do anúncio, que acolhem o anúncio e que acolhem o próprio Cristo. Explica-o Severino Dianich:

Trata-se de uma espécie de osmose, na qual aquilo que Cristo foi para o apóstolo agora o é também para mim, que creio na sua palavra. Disso deriva uma característica essencial da comunicação do evangelho: esta [comunicação] se transforma necessariamente numa comunhão, isto é, numa profunda relação interpessoal. [...] A comunhão é antes de tudo um encontrar-se de pessoas concretas que se conhecem, que se falam, que se comunicam a sua experiência de Cristo e que chegam assim a possuir em comum aquilo que para cada um é o valor mais profundo da própria vida, isto é, o próprio encontro com Cristo. [...] Só quem sabe por experiência pessoal o que significa ter comunicado a outros o próprio viver de ["de" de origem] Cristo e o ter recebido de outros a sua experiência de Cristo, sabe o que quer dizer (uma) Igreja. (DIANICH, 1981, p. 58).

Horizonte, Belo Horizonte, v. 17, n. 53, p. 1120-1169, maio/ago. 2019 - ISSN 2175-5841 
Essa é a estrutura absolutamente originária, que se deu no primeiro nascimento da Igreja (cujo momento paradigmático é a vinda do Espírito, a pregação de Pedro, a adesão de um grande número de ouvintes, a vida da comunidade cristã) (At 2,1-47) e se dá em cada nova eclesiogênese (nova geração da Igreja), pois toda vez que a Palavra anunciada na fé é acolhida na fé, tem-se aquela realidade absolutamente essencial e fundamental do ser da Igreja, que é a comunhão, na graça, de dois ou mais no Senhor Jesus, morto e ressuscitado para a nossa salvação, ou seja, para a nossa "comunhão com o Pai e com o seu Filho Jesus Cristo". Aliás, uma realidade que tem sua origem, sua forma e sua meta na Trindade Santa: "A graça de Nosso Senhor Jesus Cristo, o amor do Pai e a comunhão do Espírito Santo estejam convosco" (2Cor 13,13) (FORTE, 1987).

Uma leitura atenta do Novo Testamento mostra como a proclamação da Palavra é a prática fundamental no processo de instituição e de crescimento da Igreja. Os Atos dos Apóstolos têm uma fórmula própria para expressar a edificação da Igreja: "A palavra de Deus crescia" (At 6,7; At 12,24; At 13,49; At 19,20). A Palavra faz nascer e crescer a Igreja; crescimento da Palavra e edificação da Igreja caminham juntos. Neste sentido, pode-se dizer que

o tema do livro dos Atos dos Apóstolos não é nem a história da Igreja, nem a atividade do Espírito, mas o desenvolvimento da Palavra. O verdadeiro protagonista dos Atos dos Apóstolos é o “logos”, a Palavra [...] Como para Paulo em Rm 9,8ss., a Igreja é para Lucas uma creatura verbi; os crentes são definidos pela acolhida da Palavra $(8,14$; 11,11-17; 17,11; Lc 8,13) e chamados "ouvintes da Palavra". (MARGUERAT, 1999, p. 57).

No Novo Testamento, de fato, a Igreja tem a sua origem, se desenvolve e se propaga no interior de um processo dinâmico e complexo de "traditio-receptio" (transmissão-recepção ou acolhida), isto é, uma estrutura de relação e de comunicação que a faz existir. 


\title{
1.1 A comunicação incessante da Palavra
}

Não se trata, porém, meramente de um "ato" - instantâneo, pontual, sem contexto, quase mágico - mas de um processo "instituinte" originário e permanente! As categorias sociológicas de "instituinte" e "instituído" talvez sejam as que melhor ajudam a entender a dinâmica da primeira origem da Igreja, do surgimento de cada nova comunidade eclesial e da sua constante edificação pela Palavra. Justifica Routhier:

\begin{abstract}
Pensar que a Igreja seja incessantemente instituída, fundada, cresça e se desenvolva a partir da ação da Palavra ou a partir dos atos instituintes que são o anúncio e a acolhida da Palavra, supõe que se leve a sério o fato de que a Igreja deva ser sempre construída. Significa reconhecer que ela nunca está simplesmente constituída de uma vez por todas, instituída na origem e que agora não se trata senão de pensá-la em termos de uma instituição a ser perpetuada ou mantida. Significa pensar que a Igreja esteja sempre em fase de construção. Esta perspectiva não é espontânea; ao contrário, temos dificuldade de imaginar que é necessário, com a força do Espírito, instituir a Igreja e não simplesmente, quando esta parece em perigo, remediar os problemas do telhado com um balde no chão, diminuir os vazamentos, consertar o que está estragado [...]. (ROUTHIER, 2011, p. 119).
\end{abstract}

Sem qualquer prejuízo do processo "criacional" originário da Igreja nas missões escatológica de Cristo e do Espírito (PIÉ-NINOT, 2016, p. 334), e da fundação e edificação (oikodomé) das primeiras comunidades cristãs (PENNA, 2011) - todas chamadas "Igrejas" no Novo Testamento (1Cor 1,2; 2 Cor 1,1; Gl 1,2; 2Ts 1,2 etc.) - "sobre o fundamento dos apóstolos e dos profetas" (Ef 2,20) - que tem um caráter único e fundante - a Igreja tem que ser pensa também em seu permanente "devir": como um povo peregrino ( $\mathrm{Hb}$ 13,14), como um corpo cujos

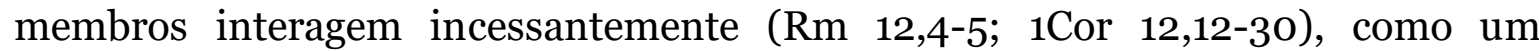
templo de pedras vivas $(1 \mathrm{Pd} 2,5)$ em incessante construção (1Cor 3.9c-15).

Pensar, portanto, a Igreja no seu nascer originário não é um exercício de arqueologia teológica, mas a descoberta de que elementos e de quais procedimentos eclesiais entram em jogo em todo nascimento e em toda edificação da Igreja. A Igreja, com efeito, não é um museu, nem uma biblioteca, nem um banco de dados, nem se reproduz por clonagem. É uma realidade pessoal, 
interpessoal, social e histórica, e, por isso, é absolutamente necessário encontrar, em cada "hoje" da história e em cada diferente contexto social e cultural, práticas ou gestos instituintes, um saber fazer nascer e renascer e refazer de importância capital. Não se pode dormir sobre o "instituído"; ocorre "instituir" sempre de novo (LAPASSADE， 1971; ILLICH， 1973；CASTORIADIS， 1975； LOURAU， 1975; FRIEDENBERG, 1975). Diz o Documento Preparatório:

Ser Igreja significa ser povo de Deus (EG 114), encarnado "nos povos da Terra" (EG 115) e em suas culturas [...]. A Igreja é chamada a aprofundar sua identidade em correspondência às realidades de seu próprio território e a crescer em sua espiritualidade escutando a sabedoria de seus povos. Por isso, a Assembleia Especial para a Região Pan-Amazônica é chamada a encontrar novos caminhos para fazer crescer o rosto amazônico da Igreja. (SÍNODO PARA A AMAZÔNIA, 2018, n. 12).

\section{2 "Não só de pão vive o homem, mas de toda palavra da boca de Deus"}

Para termos uma Igreja viva e contar com comunidades vivas que possam vir a ter "ministros próprios" para presidi-las e presidir a sua Eucaristia e lançá-las à missão - como têm feito arduamente e belamente tantas Igrejas na Amazônia (CLEMENTE NETO, 2018) - precisamos valorizar, intensificar ou, conforme o caso, retomar ou, em certas situações mais desafiadoras, iniciar uma ação sólida e necessariamente complexa em termos de "início", "nascimento" e "construção" permanentes da Igreja e das comunidades. É preciso ouvir o que o Espírito está dizendo à(s) Igreja(s) para que esta(s) possa(m) anunciar a Palavra, que, por sua própria força (1Ts 2,14), e pela força do Espírito (1Cor 12,3.8), sempre de novo suscita e ressuscita o povo de Deus, o templo do Espírito, o Corpo de Cristo: Igreja encarnada capaz de realística e humildemente repensar - na Amazônia - sua presença escassa "em relação à imensidão do território e de sua diversidade cultural”. (SÍNODO PARA A AMAZÔNIA, 2018, n. 14)

Que formas deveria tomar hoje, nos mundos amazônicos, o anúncio da Palavra, se estamos convencidos de que o gesto de "instituir" é uma prática originária e fundamental, poderosa como foi na boca dos profetas, na missão de 
Jesus, na obra dos apóstolos? A Palavra tem que ocupar um espaço amplo, diversificado e qualificado nas comunidades:

seu testemunho no dia a dia da vida; sua transmissão no seio das famílias praticantes; o reunir-se em torno da Palavra em círculos bíblicos, células, pequenos grupos; o ser fonte de inspiração e critério das várias equipes, serviços, pastorais, associações e movimentos; um seu conhecimento mais sistemático em cursos bíblicos e teológicos. (PAULO VI, 1974, nn. 17-24). Em suma: precisamos sentir a urgência de semear a Palavra em toda pessoa, em toda a comunidade e em todas as comunidades, de modo que ela "anime" realmente toda a vida, a pastoral e a missão! (CNBB, 2019).

A Palavra, em fecundo diálogo com os ambientes reais, buscando ouvir e responder às mais diversas inquietações, deve cair como chuva criadeira no coração das pessoas, de suas leituras da realidade, de suas decisões e ações. Se a Palavra - Palavra que narra a história de Deus com os homens e mulheres, e palavras humanas que decifram para hoje a presença de Deus na história - não for liberada no coração da vida, a Igreja não será “instituída” sempre de novo, sempre de novo edificada e desafiada para a missão.

Não sendo assim, a própria Celebração da Palavra de Deus (CNBB, 2018) aos domingos - fundamental sob vários aspectos - perderá a importância que se lhe atribui. Em muitos lugares, esta prática ainda não está implantada. Em outros, a comunidade não lhe dá o valor que tem. Há comunidades que perderam o gosto de os irmãos se encontrarem, o fervor primitivo e o ardor missionário. É mister repetir-lhes aquela palavra de Jesus que revela o caráter sacramental de toda reunião em seu nome: "Onde dois ou três estiverem reunidos em meu nome, ali eu estarei, no meio deles” (Mt 18,20). Será que não sabem que foi o próprio Concílio Ecumênico Vaticano II que recomendou a Celebração da Palavra de Deus? Ouçamos:

Promova-se a celebração da Palavra de Deus nas vigílias das festas mais solenes, em alguns dias feriais do Advento e da Quaresma e nos domingos e dias de festa, especialmente onde não houver sacerdote; neste caso, será um diácono, ou outra pessoa delegada pelo Bispo, a dirigir a celebração. (SACROSANCTUM CONCILIUM 35, 4). 
Por toda parte onde a Celebração da Palavra, especialmente na América Latina, foi assumida com entusiasmo e se incorporou à vida vivida da comunidade, esta prática fomentou e fortaleceu a vida cristã, o desenvolvimento comunitário e o compromisso evangélico de transformar a sociedade segundo a vontade de Deus. Uma pequena semente cresceu e tornou-se árvore frondosa e fecunda, de modo que os pássaros do céu vêm abrigar-se nos seus ramos (Mt 13,32). (ALMEIDA, 1989, p. 23-28)

\subsection{Da celebração da Palavra à celebração da Eucaristia}

À medida, porém, que a Palavra cumpre a função para a qual é (sempre de novo e sempre nova) lançada, a comunidade deve poder dar graças, não só no sentido genérico da palavra, mas em seu sentido forte, deixando-se edificar também pela Eucaristia (1Cor 11,17-34), palavra que esconde a suprema açãooração de Jesus na Última Ceia, na cruz e em alguns encontros pós-pascais com os discípulos (Lc 24,30-31.35; Jo 21,9-14).

A Igreja, concretamente, as comunidades não podem ser nem se ter por plenamente criadas e edificadas sem a celebração da Eucaristia. O sacramento é a forma mais plena e intensa e eficaz da palavra proclamada pela Igreja:

A anamnese é na Igreja a palavra mais central, porque torna presente, no modo mais intenso e real, como nossa salvação, aquilo que diz. Por isso toda outra palavra na Igreja, no fundo, não pode ser senão a preparação, explicação e defesa desta única palavra, na qual a Palavra encarnada de Deus entra como nossa salvação no nosso âmbito espaciotemporal. (RAHNER, 1973, p. 86).

Ao lado da anamnese, a epiclese, co-essencial à celebração sacramental, mormente da Eucaristia. Comenta Nicolau Cabásilas (1320-1390), destacado teólogo leigo bizantino, em sua obra A Explicação da Divina Liturgia: 
[O sacerdote] narra aquela ceia que incute temor e como [o Senhor] antes da paixão confiou a seus santos discípulos isto [o que nela foi instituído]; e como tomou o cálice e como tomou o pão e, depois de ter dado graças, [os] consagrou; e como disse as palavras por meio das quais manifestou o sacramento; e depois de ter proclamado aquelas mesmas palavras se prostra e ora e suplica para que aquelas palavras divinas do Filho unigênito e [nosso] Salvador se harmonizem também com os dons apresentados, de forma que, tendo recebido seu santíssimo e onipotente Espírito, sejam transformados, o pão em seu corpo precioso e santo, e o vinho em seu sangue imaculado e santo. Depois destas orações e destas palavras, toda a ação sagrada está concluída e realizada, os dons são consagrados, o sacrifício está realizado, a grande e sagrada vítima, imolada pelo mundo, jaz lá sobre a sagrada mesa à vista [de todos]. (CABÁSILAS, Expositio divinae liturgiae 27).

É necessário, portanto, avançar do âmbito da Palavra ao âmbito dos Sacramentos, e vice-versa. Os sacramentos só podem ser autenticamente compreendidos a partir da lógica dos sinais: "Sacramentum ponitur in genere signi”. (TOMMASO D’AQUINO, La Somma teologica III, q. 6o, a. 1.) A lógica dos sinais responde às exigências integrais do mundo humano e da comunidade humana; seu terreno é o terreno da intuição, da fantasia, da emotividade, da poesia, da tradição... Diz o mesmo Dianich, que nos ajudou a ver o anúncio da Palavra na origem da Igreja:

Uma salvação destituída dos ritos sacramentais não penetraria em todo este vasto mundo no qual o homem vive grande parte da sua vida de relação e de comunidade. Portanto, os sinais sacramentais levam a comunidade eclesial à sua dimensão integral. Se eles são gratuitos no que respeita aos conteúdos da salvação, abstratamente considerados, eles se mostram necessários para uma salvação que queira ser plenamente humana e histórica, realizada numa comunhão concreta e completa dos crentes. (DIANICH, 1981, p. 99).

Passemos, pois, ao segundo ponto de nossa reflexão: a necessidade da celebração da eucaristia para a plenificação da Igreja, concretamente, para a plenificação das comunidades atualmente sem acesso regular à Eucaristia.

\section{A Eucaristia faz a Igreja "Ecclesia de Eucharistia"}

Quando dizemos que "a eucaristia faz a Igreja", não estamos nos referindo à reserva eucarística, presente nas sedes paroquiais e em inúmeras capelas Brasil afora; nem à distribuição da comunhão no contexto das Celebrações da Palavra; 
nem à comunhão fora da missa, prática testemunhada já na Igreja antiga, porém somente para cristãos perseguidos ou na prisão, doentes impedidos de participar da sinaxe eucarística da comunidade, idosos presos a um leito em sua própria casa ou nalgum hospital.

Estamos falando da celebração consciente, ativa e frutuosa da Eucaristia, conhecida também por outros nomes: "fração do pão" (1Cor 10,16; At 2,42.46; 20,7.11; 27,35), "eucaristia" (Justino, Apologia I, 66-67), "oblação" ou "sacrifício" (Tertuliano, Cipriano, Agostinho, alta Idade Média), "sacrum” (sagrado) (entre os abissínios, coptas), "dominicum" (celebração do Cristo, o Senhor/Dominus) (em Roma e na África nos séculos III e IV), missa (no Ocidente, depois do século IV), "liturgia" ou "santa liturgia" (no Oriente, entre os gregos, depois do século IX). (JUNGMANN, 1951, p. 213-220.)

Concentraremos nossa reflexão em três pontos: a) os textos paulinos sobre a Eucaristia; b) os Santos Padres; c) a "lex orandi, lex credendi".

\subsection{Eucaristia e Igreja nas cartas de Paulo}

Paulo inaugura uma tradição que se estende tranquila e sólida por todo o primeiro milênio, segundo a qual a eucaristia faz a Igreja-Corpo de Cristo: "O cálice da bênção que abençoamos, não é comunhão (koinonía toû) com o sangue de Cristo? O pão que partimos, não é comunhão (koinonía) com o corpo de Cristo? Visto que há um só pão, nós, embora muitos (hoi polloi = a multidão), somos um só corpo, visto que todos participamos (ek toû... metekhomen) desse único pão" (1Cor 10,16-17).

Na sua argumentação contra a consumação da carne sacrificada aos ídolos por parte de um cristão (1Cor 8,1 - 11,1), Paulo trabalha com uma crença que ele herdou do Israel antigo: "os que comem as vítimas imoladas estão em comunhão com o altar" (1Cor 10,18; Ex 32,6; Lv 7,6.15; Dt 12,11s; 18,1.4), símbolo da própria divindade cultuada. 
Na Ceia, os fiéis, participando do "cálice de bênção que abençoamos" "comunhão com o sangue de Cristo" - e do "pão que partimos" - "comunhão com o corpo de Cristo" - são postos numa comunhão estreitíssima com o Cristo morto e ressuscitado. É a dimensão primeira da Eucaristia: "vertical”. A “comunhão" dos fiéis com o "sangue" e o "corpo" de Cristo gera e fundamenta a solidariedade dos fiéis entre si: comer juntos do único pão (o corpo eucarístico de Cristo) cria vínculos tão profundos que os muitos comensais formam um só corpo (o corpo eclesial de Cristo). Os fiéis são um só corpo (eclesial) porque participam do único corpo (eucarístico) de Cristo! (BARBAGLIO, 1989, p. 291-296). É a dimensão consequencial da eucaristia - "horizontal" - introduzida por um ótı (porque), a indicar um nexo causal entre "um só pão" e "um só corpo", como diz o Cardeal Martini:

A eucaristia não é só princípio do amor "vertical" que une Deus e homem, é também sinal eficaz e ativo da comunhão "horizontal" entre os crentes. A eucaristia, segundo a conhecida afirmação medieval, constrói a Igreja. As observações pastorais de 1 Cor $11,17-33$ nos revelam que a moldura concreta da celebração eucarística era a de um banquete fraterno, a ágape, uma verdadeira e própria festa de amor recíproco. Esta unidade nascia justamente da participação no único corpo de Cristo, que tornava os cristãos uma só pessoa: "Os muitos são um só corpo porque participam de um só pão” (1Cor 10,17). (MARTINI, 1979, p. 5).

Paulo aprofundará e tirará algumas consequências desta dimensão eclesialsocial da eucaristia no capítulo seguinte, onde censurará os coríntios pelas divisões que há entre eles (na verdade, entre ricos e pobres) quando se reúnem "em assembleia" ("en ekklesía”) (1Cor 11,17-34), no capítulo 12, ao falar da unidade do corpo e da diversidade de membros e de carismas (1Cor 12,12-27), e no capítulo final, quando dará recomendações práticas sobre a coleta em favor da Igreja de Jerusalém (1Cor 16,1-4). Note-se que, aqui, ele estabelece uma relação entre a coleta para os pobres de Jerusalém e a celebração da Eucaristia: "No primeiro dia de cada semana, cada um separará o que conseguiu poupar" (1Cor 16,2). Não se poderia sublinhar melhor a ligação entre a oferta eucarística e a oferta fraterna! Sendo os coríntios melhores em falar que em agir, Paulo vai se alongar na 2Coríntios sobre o projeto da coleta (2Cor 8-9), chamando-a justamente de "koinonía" (comunhão) $(2$ Cor 8,4). 
Se alargássemos o olhar para além dos textos paulinos, teríamos que dizer que o Novo Testamento, em seu conjunto, apresenta a comunhão entre Cristo e a Igreja essencialmente de duas formas:

como comunhão com o Cristo e como comunhão no Cristo. Não parece que haja alternativa, antes complementação, e esta complementação se encontra um pouco em todas as camadas do Novo Testamento [...]. A comunhão eucarística Cristo-Igreja leva consigo, de fato, à comunhão fraternal dos membros do Cristo entre si (1Cor 12,26; At 4,32; etc.), e esta lógica não é acidental ou marginal, mas é absolutamente fundamental, a tal ponto que há que se questionar a autenticidade $d$ a comunhão CristoIgreja quando ela (a comunhão) não se exprime em comunhão fraternal de todos os que a ceia une ao Cristo [...]. A comunhão com Cristo faz da Igreja um corpo, seu corpo; é a razão pela qual a Igreja não poderia existir sem Eucaristia; daí porque também a epiclese clássica invoca o Espírito "sobre nós e estes dons", para que uns e outros tornam-se corpo de Cristo. (ALLMEN, 1968, p. 71- 79).

\subsection{Eucaristia e Igreja nos Santos Padres}

Em toda a literatura patrística, eucaristia e Igreja aparecem tão unidas que não se pode falar de uma sem pensar na outra. Do vastíssimo conjunto de testemunhos patrísticos levantados e aprofundados por De Lubac (LUBAC, 1996) recolhemos alguns:

Cipriano de Cartago (+ 258), incansável defensor da unidade da Igreja, recorre à metáfora - presente também na Didaché e em Inácio de Antioquia - dos muitos grãos que formam o único pão:

Quão sólida seja a unanimidade cristã [...] o declaram por si mesmos os sacrifícios do Senhor. Com efeito, quando o Senhor chama seu corpo o pão, que é feito de muitos grãos reunidos, com isto significa a união de todo o povo cristão, que ele levava em si. Quando chama seu sangue o vinho, que é uma só bebida de muitos cachos, significa ainda a grei que somos nós, provenientes de uma multidão reconduzida à unidade. (CIPRIANO. Epistola 69, c. 5, n. 2).

Justificando por que Paulo fala de “comunhão" e não de "participação”, em 1Cor 10,16, João Crisóstomo (+ 407) esclarece: 
Porque quis mostrar algo mais, isto é, para manifestar uma grande união. Não é para participar ou para receber que nós comungamos, mas é sobretudo para tornarmo-nos uma coisa só. De fato, aquele corpo [assumido na encarnação] tornou-se uma coisa só com Cristo, assim também nós nos tornamos uma só coisa com ele por meio deste pão [...]. $\mathrm{O}$ que é o pão? $\mathrm{O}$ corpo de Cristo! $\mathrm{O}$ que se tornam aqueles que o recebem? O corpo de Cristo! Não muitos corpos, mas um só corpo. De fato, como o pão, embora composto de muitos grãos, é uma só coisa, e os grãos ainda que presentes não se percebem mais pois sua diferença desaparece na união, assim também nós estamos unidos uns aos outros e a Cristo. Não é que tu te nutres de um corpo e o outro de outro, mas todos nós nutrimos do mesmo [...]. Ora, se todos [participamos] do mesmo e nos tornamos uma só coisa, por que então não manifestamos o mesmo amor e não nos tornamos consequentemente uma coisa só? (JOÃO CRISÓSTOMO. In Epistulam I ad Corinthos 24,2: PG 61, 200).

Numa instrução dirigida aos neófitos, Agostinho (+ 430), para o qual “a Igreja tem com a eucaristia uma relação como entre causa e efeito, entre meio e meta e, ao mesmo tempo, como entre sinal e realidade" (LUBAC, 1996, p. 33), é incisivo:

Aí se diz: O Corpo de Cristo. E respondeis: Amém. Sede, pois, membros do corpo do Cristo, para que seja verdadeiro o vosso Amém. - E por que este mistério é feito com o pão? - Nós não dizemos nada de nosso. Escutemos o Apóstolo, que, falando deste sacramento, diz: "Somos muitos, nós os muitos, um só corpo, um só pão". Compreendei e alegraivos. Unidade, piedade, caridade! Um só pão: e o que é este pão único? Um só corpo, feito de muitos. Pensai que o pão não se faz com um só grão, mas com um grande número. Durante os exorcismos, éreis de alguma maneira sob a mó. No batismo fostes embebidos de água. O Espírito Santo veio então em vós como o fogo que assa a massa: Sede, pois, o que vedes e recebei o que sois... Quanto ao cálice, irmãos meus, recordai como se faz o vinho. Muitos grãos pendem do cacho, mas o líquido que escorre de todos se confunde na unidade. Assim o Senhor quis que nós lhe pertencêssemos, e consagrou no seu altar o mistério da nossa paz e da nossa unidade. (AGOSTINHO. Sermo 272 [PL 38, 1247]; Sermo 234 [PL 38, 1.116]).

\section{Cirilo de Alexandria (+ 444), que se notabilizou pela luta contra o arianismo e o nestorianismo, aborda eucaristicamente a relação unidade - individualidade:}

Para fundir-nos na unidade de Deus e entre nós, embora tenhamos cada um uma personalidade distinta, o Filho único inventou um meio maravilhoso: por meio de um só corpo, o seu, santifica os fiéis na comunhão mística, fazendo-os um só corpo consigo mesmo e entre eles. Nenhuma divisão pode sobrevir no interior do Cristo. Unidos todos com o único Cristo por meio do seu próprio corpo, recebendo-o todos, ele, uno e indivisível, nos nossos corpos, nós somos membros deste corpo único, e ele é para nós assim o vínculo da unidade. (CIRILO DE ALEXANDRIA. In Joannem 11,11: PG 74, 560). 
Leão Magno (+ 461), com a clareza e a concisão habituais, diz tudo o que a Igreja vive e crê ao comungar: "A participação do corpo e do sangue de Cristo não faz outra coisa senão transformar-nos naquilo que tomamos". (LEÃO MAGNO; Sermo 63,7: PL 54, 357c).

Três séculos depois, João Damasceno $(+749)$, em quem ressoa toda a tradição grega, mantém o mesmo ensinamento: "Se o sacramento é uma união com Cristo, e ao mesmo tempo uma união de uns com os outros, [ele] nos proporciona em todos os sentidos a unidade com aqueles que como nós o recebem”. (JOÃO DAMASCENO; De fide orthodoxa, 1.4, c. 13: PG 94, 1154).

Henri de Lubac, em 1938, quando escreveu Catolicismo. Aspectos sociais do dogma, após analisar alguns poucos testemunhos patrísticos, se deu claramente conta do nexo - da recíproca relação constitutiva - entre Eucaristia e Igreja:

\begin{abstract}
Seguindo os Padres, que não tinham feito senão comentar os textos da Escritura e da Liturgia, toda a Idade Média latina viveu desta doutrina. Teólogos e pregadores, exegetas e liturgistas, polemistas e poetas a expõem cada um por seu turno. A todos parece tão central que as suas discussões a deixam intacta. Como não é o privilégio da especulação sapiente, assim também não é o bem particular de uma escola. Partidários de Pascásio Radberto, de Rabano Mauro ou de Ratramno, de Floro e de Amalário; defensores do "metabolismo ambrosiano", do "dinamismo agostiniano" ou do "simples realismo romano" [...], qualquer que seja a relação que estabelecem entre "o corpo nascido da Virgem" e o corpo eucarístico; que na sua afirmação da presença sacramental ponham o acento no "mysterium" ou na "veritas", todos são unânimes: o fruto essencial do sacramento é a unidade. (LUBAC, 1978, p. 60).
\end{abstract}

Em Corpus Mysticum. A Eucaristia e a Igreja na Idade Média, obra de 1949, a análise de centenas de testemunhos ao longo de todo o primeiro milênio, solidificou sua descoberta da década anterior; é aí que ele exprime aquilo que se tornará o axioma "A Igreja faz a Eucaristia e a Eucaristia faz a Igreja": “[...] Nutridos com o corpo e com o sangue do Salvador, os seus fiéis são todos "saciados por um só Espírito", que faz deles verdadeiramente um só corpo. É, portanto, em sentido estrito, que a Eucaristia faz a Igreja". (LUBAC, 1996, p. 123) "Toda a Idade Média latina viveu esta doutrina [...] todos são unânimes: o fruto essencial do sacramento é a unidade”. (LUBAC, 1978, p. 60). 


\subsection{Lex orandi, lex credendi: “A norma da oração é a norma da fé"!}

"Lex orandi, lex credendi" é a forma abreviada da frase "para que a norma da oração estabeleça a norma da fé”, que aparece, a primeira vez, no Indiculus de gratia, um documento, atribuído a Próspero de Aquitânia, da cúria romana do século V.

Em seu contexto primitivo, em sentido estrito, ela significaria isso: da necessidade da oração (de súplica) decorre o dever da necessidade da graça. Com o passar do tempo, porém, se tirou daí um princípio teológico ou mesmo um axioma: a liturgia é uma regra de fé, um testemunho da infalível fé da Igreja.

Pergunta Giraudo: "Se a norma do orar estabelece a norma do crer, quais serão os critérios pelos quais se pode reconhecer num texto litúrgico a norma do orar, a lex orandi? Evidentemente não será suficiente um formulário ser utilizado uma ou mais vezes para que se possa falar de lex orandi." O critério fundamental é o da universalidade: orações sacerdotais "transmitidas pelos apóstolos", que "são celebradas uniformemente em todo o mundo e em toda a Igreja católica”. Não são individuais, mas oficiais”. Os presidentes das santas assembleias não oram por si sós, mas "geme com eles toda a Igreja" (GIRAUDO, 2003, p. 17).

É conhecido outro critério, elaborado por um teólogo da mesma época do Indiculus, o semipelagiano Vicente de Lérins: "Na Igreja católica deve-se cuidar sobremaneira de manter o que foi crido em toda parte, sempre e por todos. Pois é verdadeira e propriamente católico o que [...] abraça quase universalmente tudo. Mas isso acontecerá só se seguirmos a universalidade, a antiguidade, o consenso unânime. Seguiremos a universalidade, se afirmarmos que é verdadeira só a fé que a Igreja inteira professa por todo o orbe terrestre; a antiguidade, se de nenhum modo nos afastamos do sentido que manifestamente abraçaram nossos santos antepassados e pais; e seguiremos igualmente o consenso unânime, se, em relação a essa mesma antiguidade, nos ativermos às definições e às sentenças de todos, ou pelo menos, de quase todos, os sacerdotes e os mestres. (VICENTE DE LÉRINS, Commonitorium 2 (PL 50, 640).

Se adaptarmos à lex orandi o tríplice critério que Vicente de Lérins elabora no que diz respeito à lex credendi, poderíamos dizer que se reconhece a lex orandi naquilo que "em toda parte, sempre e por todos foi objeto de oração". Ou seja, 
“dever-se-á dizer que um texto litúrgico é lex orandi e, como tal, normativo da fé, só quando responde aos critérios de universalidade, da antiguidade e do consenso unânime" (GIRAUDO, 2003, p. 18).

A mesma ou semelhante ideia veiculada pelo axioma "lex orandi, lex credendi" encontramos em Orígenes (+245):

Mas, quando oramos, não fazemos vanilóquios, mas teologia!"; em Basílio de Cesareia (+379): "Como fomos batizados, assim devemos crer"; Evágrio Pôntico (+399): "Se és teólogo, rezarás verdadeiramente. E se rezas, verdadeiramente és teólogo"; Lambert Beauduin (+1960): "Dizeime como orava Agostinho em Hipona, Ambrósio em Milão, Isidoro em Sevilha, Gregório em Nissa, Crisóstomo em Constantinopla, e vos diremos todo o Credo de suas respectivas Igrejas. (BEAUDUIN, 1912/13, p. 143).

Ou, no 'grego da terra', na linguagem concreta e simples que também um eminente pesquisador das Anáforas ou Orações Eucarísticas, sabe usar:

Quereis saber o que é a eucaristia? Abri os missais das Igrejas! Lede aquela oração com a qual desde sempre a Igreja faz a eucaristia! Missal Romano: Cânon Romano. Missal Copta-Alexandrino: Anáfora de Serapião. Missal Bizantino-Eslavo: Anáfora de São Basílio. Missal CaldeuMalabar: Anáfora de Addai e Mari! (GIRAUDO, 2003, p. 20).

Dito isso, demo-nos conta, agora, de três modos (talvez 'modelos') de relação entre "lex orandi" e "lex credendi" na história da Eucaristia. Não se trata de um mero exercício acadêmico de arqueologia histórica. Esses modelos, com efeito, estão presentes, em gradações diversas, em geral de forma subliminar e não refletida, na nossa maneira de pensar e na nossa maneira de rezar e viver a Eucaristia. Mesmo com o Vaticano II e sua eclesiologia eucarística, que recupera o paradigma eucarístico do primeiro milênio, muitos de nós - no clero e no laicato fomos moldados e nos alimentamos pelo paradigma do segundo milênio. Toda a vigilância é pouca para nos prevenir de elementos pouco católicos - no sentido de universalidade no espaço, no tempo e no consenso - contidos no pacote da "reviravolta" eucarística do reino dos franco-germânicos, que consumimos como prato tradicional de origem controlada! 


\subsubsection{Primeiro milênio Eucaristia e Igreja na "lex orandi": circularidade}

Tendo ouvido a Escritura e os Santos Padres (2.1 e 2.2), lancemos nosso olhar, agora, sobre a Liturgia, mais precisamente, a oração com a qual a Igreja desde os seus primórdios faz a Eucaristia: a Anáfora, a Oração Eucarística, o Cânon.

A oração eucarística, enquanto discurso oracional que a comunidade reunida dirige ao seu parceiro divino, é um corpo vivo e palpitante, cujos membros interagem em função do conjunto.

Isto salta aos olhos quando prestamos atenção às suas ascendências veterotestamentárias e judaicas. A observação atenta dessas orações nos ajuda a captar a dinâmica literário-teológica da oração litúrgica, que, com suas duas articulações maiores - louvor / ação de graças e súplica - conecta todos os elementos internos do discurso oracional.

Nestas orações, mesmo quando tenham inserido como um "enxerto literário" (émbolon) a "narração institucional" - comumente chamada "consagração" - vê-se que esta não pode subsistir sozinha. Ou seja, não se pode isolar a "consagração", como se ela, sozinha, representasse a eficácia de toda a oração eucarística. É enquanto membro vivo do corpo literário-teológico que é a oração eucarística que ela desprende todas as suas possibilidades dinâmicas. A oração eucarística, com efeito, deve ser encarada como um organismo perfeitamente estruturado pela [inter] conexão dos seus membros. Neste sentido, a "narração institucional" ou "consagração" interage, sempre da mesma maneira, com a sucessiva anamnese e, em modalidades que variam, com a dupla epiclese: a primeira, que pede a transformação do pão e do vinho no corpo e no sangue sacramentais de Cristo, e a segunda, que pede a transformação dos comungantes no corpo eclesial de Cristo. 
Nas anáforas ocidentais, as palavras da narração institucional e a anamnese estão enquadradas por duas epicleses: a epiclese sobre as oblatas pede a intervenção divina para a sua transformação no corpo e no sangue sacramentais de Cristo, a epiclese sobre os comungantes pede que os comungantes sejam transformados no corpo eclesial de Cristo. Mesmo encontrando-se materialmente separadas, as duas súplicas constituem uma única e indivisível súplica.

Nas liturgias orientais, o caráter unitário das duas epicleses é bem mais claro, uma vez que a epiclese sobre as oblatas vem depois da narração institucional e a sua anamnese, isto é, imediatamente antes da epiclese sobre os comungantes. O pedido soa assim: "Manda o teu santo Espírito sobre este pão e este vinho, "a fim de que" (hína/ut) ele transforme o pão no corpo e o vinho no sangue do teu Cristo, "a fim de que" (hína /ut), comungando, sejamos transformados num só corpo". Em algumas anáforas orientais - o caso típico é a de Basílio - as duas epicleses chegam a ser cruzadas, num eloquente quiasma literário-teológico: "Manda o teu Espírito sobre nós e sobre estes dons, para que transforme os dons no corpo sacramental, a fim de que, comungando, nós sejamos transformados no corpo eclesial". Os méritos desta configuração quiástica são diversos: a) evidencia a ação de cada uma das pessoas divinas; b) precisa que toda a ação eucarística converge para a Igreja, ou seja, para aquele corpo que - no ritmo histórico-salvífico do “já" e do "ainda não" - se constrói na sinaxe eucarística; em linguagem escolástica, o termo último - e, portanto, a finalidade própria da celebração eucarística - não é o "corpo sacramental" (o sacramentum et res), mas o "corpo eclesial" (a res tantum), isto é, a edificação da Igreja (como corpo de Cristo) (GIRAUDO, "Eucaristia e Chiesa", 2010, p. 655); ou seja, a epiclese mais importante - aquela para a qual a outra é ordenada - é o pedido para a nossa transformação no corpo eclesial; c) a transformação dos comungantes em corpo de Cristo exige a transformação das oblatas em corpo de Cristo, o que se faz, normalmente, buscando na Escritura o lugar teológico escriturístico próprio e o encontra na narração institucional - inserido tal e qual no corpo da oração - do corpo "que está para ser dado" e do sangue "que está para ser derramado", no pleno respeito da conotação futura. 
Nas novas orações eucarísticas, esta dinâmica é muito mais evidente, sobretudo na Oração Eucarística II. Se tirarmos (literariamente e com fim didático) o relato institucional e a anamnese, temos o seguinte resultado oracional: "Santificai, pois, estas oferendas, derramando sobre elas o vosso Espírito, a fim de que se tornem para nós o Corpo e o Sangue de Jesus Cristo, vosso Filho e Senhor nosso" (epíclese sobre as oblatas) "e vos suplicamos que, participando do Corpo e do Sangue de Cristo, sejamos reunidos pelo Espírito Santo num só corpo” (epiclese sobre os comungantes).

O que se pede no foco principal da oração eucarística (prex) - "a fim de que, comungando, sejamos transformados num só corpo" - culmina na comunhão (ritus). Ainda que a teologia especulativa do segundo milênio tenha respondido, como num tributo à crise berengariana e à teologia dialética, que a celebração eucarística se destina a tornar presente nas espécies consagradas aquele Jesus que cada fiel quer receber na sagrada comunhão, a lex orandi nunca deixou de transmitir um ensinamento muito mais rico.

Explica serenamente convicto e próximo ao arroubo místico o circunspecto mestre Cesare Giraudo, ao final de longa e grave trajetória:

A epiclese para a nossa transformação escatológica, justamente entendida como chave de leitura última da celebração eucarística, nos obriga a compreender que a presença real não nos é dada só para que possamos adorar Cristo sob as espécies eucarísticas e, ainda, que a comunhão não nos é dada principalmente para que possamos encontrar e receber no coração o amigo Jesus, ao qual dar por alguns instantes férvida companhia. O Senhor não instituiu a Eucaristia em função dos nossos olhos que o contemplam, nem dos nossos joelhos, que o adoram. Ele a instituiu - primo e per se (em primeiro lugar e de per si) - em função das nossas bocas, que dele se nutrem. Em suma, a instituiu para que a comamos: "ut sumatur", diz Trento (DS 1643). (GIRAUDO, 2010, p. 657). 


\subsubsection{Segundo milênio Eucaristia e Igreja na "lex credendi": curto-circuito}

Se, no primeiro milênio, pode-se dizer que, no tocante à Eucaristia, houve uma correspondência muito íntima entre a "lex credendi" e a "lex orandi", o mesmo não se pode dizer em relação ao segundo milênio. Aliás, deve-se mesmo enfatizar que, até o século IX - um pouco mais, um pouco menos - a lex orandi determinou a lex credendi; a partir, porém, do século IX, a metodologia eucarística muda.

Os Padres da Igreja, com efeito, são substituídos pelos padres da Escolástica, que se comportam como livres intérpretes de uma visão teológica que presumem professar. Para os Padres da Igreja, a lex orandi regula a correspondente lex credendi; para os teólogos dos neoconvertidos povos germânicos, a lex credendi assume o comando e, como mestre monocrática, orienta, reduz e desarticula - salvo algumas exceções entre os pré-escolásticos: Pascásio Radberto [+859], Floro de Lião [+860]), e, na baixa Idade Média, Thomas Netter de Walden [+1430) ${ }^{1}$ - a compreensão da eucaristia testemunhada pela lex orandi.

Escreve-se muito sobre a Eucaristia, mas as reflexões se referem cada vez menos às orações e aos ritos litúrgicos, tornam-se cada vez mais dialéticas, recorre-se com muita liberdade à Escritura e aos Santos Padres, tudo ou sempre com o intuito de sustentar as próprias teses (dicta probantia). Como para os demais sacramentos, as primeiras perguntas - no paradigma escolástico que vai se impondo no Ocidente a partir sobretudo do século IX - se referem à sua instituição, matéria, forma, eficácia, e os grandes eixos passam a ser a presença real, a sacramentalidade, o sacrifício. (GANOCZY, 1988, p. 71-85).

\footnotetext{
${ }^{1}$ O teólogo carmelita Netter aplicou a noção de "transubstanciação" - já desenvolvida para explicar o modo da transformação do pão e do vinho no corpo e no sangue de Cristo - para a Igreja: "A Igreja é o corpo místico de Cristo, no qual, através da recepção do batismo e da sagrada Eucaristia, são transubstanciados (transsubstantiantur) os cristãos." (GIRAUDO, 2003, p. 652).
} 
A excessiva preocupação em afirmar a verdade do corpo sacramental acarretou uma grave consequência para a teologia eucarística: perde-se a percepção da unidade e da interação entre os “dois" corpos de Cristo, isto é, entre a eucaristia e a Igreja. O resultado mais vistoso foi, de um lado, a compreensão da Igreja em chave cada vez mais jurídica, e, do outro, a eucaristia vivida em forma cada vez mais objetivista, individualista e devocional.

Enquanto, no primeiro milênio, as grandes controvérsias haviam sido trinitárias, cristológicas e pneumatológicas, nos inícios do segundo, o centro das discussões teológicas foi ocupado pela Eucaristia. Enquanto alguns defendiam um realismo maciço (Isidoro de Sevilha, Pascásio Radberto), outros defendiam diferentes formas de simbolismo e espiritualismo (Ratramno, Escoto Eriúgena, Berengário de Tours), numa polarização ‘dia-bólica' (desintegradora, divisora), pouco benéfica à complexidade da verdade.

A reação prática às posições simbolistas levou a uma floração de gestos, de atitudes e de ritos desconhecidos nos séculos precedentes: substituição do pão fermentado pela hóstia branca; o fim da comunhão na mão; a recepção da comunhão de joelhos; a criação da mesa de comunhão; a comunhão só sob a espécie do pão; a elevação da hóstia consagrada - acompanhada de exposição prolongada, toque dos sinos, afluxo dos fiéis ausentes; a elevação do cálice; uma incensação especial no momento da elevação; a genuflexão por parte do celebrante; invocações eucarísticas por parte dos fiéis no momento da consagração; a comunhão espiritual ou "manducação pelo olhar"; as procissões do Santíssimo Sacramento; as exposições e bênçãos do Santíssimo; uma configuração cada vez mais privilegiada do tabernáculo; a introdução das lâmpadas eucarísticas; a introdução do ostensório e do trono; a composição dos grandes hinos eucarísticos; a diminuição da comunhão sacramental (GIRAUDO, 2003, p. 444448). (Estamos falando da passagem do $\mathrm{I}^{\mathrm{O}}$ para o $\mathrm{II}^{\circ}$ milênio, mas parece uma descrição de manifestações muito comuns na passagem do século XX para o século XXI). 
O historiador da liturgia Jungmann lê em profundidade o que está acontecendo na passagem do primeiro ao segundo milênio:

Não se presta mais atenção ao que simboliza o sacramento: a relação entre o Corpo sacramental do Senhor [...] e seu Corpo que é a Igreja [...]. A mesma coisa para a relação do sacramento com a morte do Senhor [...]. A missa torna-se cada vez mais o mistério da descida divina, que se admira e se contempla de longe; mesmo a participação à Mesa do Senhor nos dias de festa tornou-se, para a grande massa dos fiéis, uma exceção: a Eucaristia, há tempo, não é mais o pão quotidiano. O sacramento não tem mais relação com a vida de todos os dias: é desta época que data o emprego do pão não fermentado. (JUNGMANN, 1951, p. 117).

Na prática e no pensamento do Ocidente, especialmente em área (franco)germânica, na passagem da antiguidade cristã à primeira (ou Alta) Idade Média, assiste-se a "uma reviravolta, em relação à doutrina eucarística, que teve uma influência decisiva até aos nossos dias" (GERKEN, 1977, p. 105). Estamos diante de uma dissociação entre "lex credendi" e "lex orandi", e entre Eucaristia e Igreja. Foram dez séculos de paralelismo entre o magistério da teologia e o magistério da liturgia. Giraudo conclui: "Eucaristia e Igreja [que], no primeiro milênio, procediam de "pari passo" e de comum acordo, no segundo milênio se encaminharam por vias diversas, sem mais sentir a necessidade de encontrar-se" (GIRAUDO, 2003, p. 652).

A percepção desta fratura, porém, suscitou, com grande intensidade no século XX, um conjunto de iniciativas - sob o nome de Movimento Litúrgico (que, aliás, não acabou!) ${ }^{2}$ - que desaguaram na retomada da afirmação da unidade entre Eucaristia e Igreja, na chamada "eclesiologia eucarística" 3, e numa participação mais consciente e ativa dos fiéis na celebração da Eucaristia. Aliás, foi particularmente da Alemanha e da França que vieram à luz alguns impulsos que tornaram possível e necessário uma nova ou (re)novada compreensão da eucaristia: 1) uma vertente do movimento bíblico-patrístico, começado no período

\footnotetext{
${ }^{2}$ No Movimento Litúrgico, sobressaem os nomes de Prosper Guéranger (+ 1875), Columba Marmion (+ 1923), Odo Casel (+ 1948), Maurice Festugière (+ 1950), Pius Parsch (+ 1954) Ildefonso Schuster (+ 1954), Lambert Beauduin (+ 1960), Romano Guardini (+ 1968), Josef Andreas Jungmann (+ 1975), Mario Righetti (+ 1975), Giacomo Lercaro (+ 1976), Annibale Bugnini (+ 1982), Cipriano Vagaggini (+ 1999) e tantos outros.

${ }^{3}$ No campo ortodoxo, os principais nomes são Nicolaj Afanassieff (+ 1966) - observador no Vaticano II - Georgiu Florovskij (+ 1979), Alexander Schmemann (+ 1983), loannis Zizioulas (1931 -); na área católica, destacam-se Henri de Lubac (+ 1991), Yves Congar (+ 1995), Jean-Marie Tillard (+ 2000), Bruno Forte (1949 -) e outros.
} 
entre as duas guerras mundiais, representados pela abadia de Maria-Laach e por nomes como Romano Guardini e, sobretudo, Odo Casel, com sua misteriologia (Mysterienlehre), e que inspirou uma ampla pesquisa em campo litúrgico (pensese na obra monumental de Joseph-André Jungmann, Missarum sollemnia, e de Joannes Betz sobre a patrística grega); 2) uma variante do movimento teológico, de cunho bíblico-ecumênico, com nomes como o de Franz J. Leenhardt, reformado, Joachim Jeremias, luterano, e a abadia beneditina belga de Saint-Croix d'Amay em Chevetogne; 3) uma reflexão filosófica de cunho antropológico, que, ligada à filosofia de Martin Heidegger, começou a superar uma interpretação "coisificante" da eucaristia por uma concepção em termos de "relação" transcendental, representada particularmente por Bernhard Welte e por Karl Rahner.

\subsubsection{Concílio Vaticano II Eucaristia e Igreja no Vaticano Il: reencontro}

Coube ao Vaticano II reconciliar coerentemente a lex credendi com a lex orandi, que, na celebração da Eucaristia, na verdade, nunca deixara de ensinar que o Corpo e o Sangue do Senhor são para ser por nós consumidos (sumpserimus) e, assim, nos preencher dos bens escatológicos (omni benedictione caelesti et gratia repleamur) (MISSALE ROMANUM, 16 ed. 1955, p. 241).4 Vamos, pois, a alguns dos principais textos do Concílio sobre o tema da relação entre Eucaristia e Igreja.

Lumen gentium, quando trata da missão e obra do Filho, enviado para realizar e revelar o desígnio salvífico universal do Pai, mostra como o dom de si por parte de Cristo sobre a cruz se ritualiza e atualiza na celebração da Eucaristia. A finalidade da Eucaristia, com efeito, é dupla: a) re-presentar e a-presentar-nos à obra da nossa redenção ("Toda vez que se celebra sobre o altar o sacrifício da cruz com o qual "Cristo nossa Páscoa foi imolado" (1Cor 5,7), se cumpre a obra da nossa redenção") 5; b) manifestar e produzir a comunhão eclesial ("e ao mesmo tempo

\footnotetext{
${ }^{4}$ Algumas orações após a comunhão, ademais, mencionam sua finalidade comunial ( $2^{a}$-feira da 3 a semana da Quaresma; 5 ํ domingo

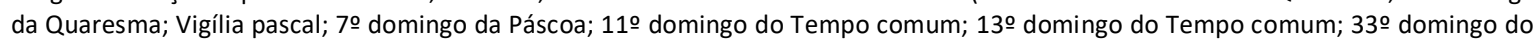
Tempo comum, etc.).

${ }^{5}$ Ver Secreta do IX Domingo depois de Pentecostes (Missal Romano).
} 
com o sacramento do pão eucarístico é representada e realizada a unidade dos fiéis que constituem em Cristo um só corpo (1Cor 10,17), à qual são chamados todos os seres humanos") ( $L G 3)$

Ao desenvolver o tema da atuação do "sacerdócio comum" - que é existencial, comum a todos os batizados e comunitário-coletivo - na celebração dos sacramentos e das virtudes, Lumen gentium 11 retoma aquela afirmação da Sacrosanctum Concilium 10, segundo a qual a eucaristia é "cume para o qual tende toda a ação da Igreja e, ao mesmo tempo, fonte da qual promana toda a sua virtude", modificando-a para "fonte e cume de toda a vida cristã". Em seguida, destaca três aspectos da Eucaristia: "participando do sacrifício eucarístico, [...], oferecem a Deus a vida divina e a si próprios com ela; oferecendo o sacrifício e recebendo a santa comunhão, tomam parte ativamente na ação litúrgica, não de maneira indistinta mas cada um segundo a própria condição; alimentando-se do corpo de Cristo na santa assembleia, manifestam concretamente a unidade do povo de Deus, unidade que o sacramento da eucaristia admiravelmente exprime e realiza” (UNITATIS REDINTEGRATIO 2).

Verdadeira pérola de eclesiologia eucarística temos em Lumen gentium 26, que desenvolve o tema do munus sanctificandi do bispo:

Revestido da plenitude do sacramento da Ordem, o Bispo é o «administrador da graça do supremo sacerdócio», principalmente na Eucaristia, que ele mesmo oferece ou providencia para que seja oferecida, e pela qual vive e cresce a Igreja. Esta Igreja de Cristo está verdadeiramente presente em todas as legítimas comunidades locais de fiéis, as quais aderindo aos seus pastores, são elas mesmas chamadas igrejas no Novo Testamento. Pois elas são, no local em que se encontram, o novo Povo chamado por Deus, no Espírito Santo e com plena segurança (cfr. 1Ts 1,5). Nelas se congregam os fiéis pela pregação do Evangelho de Cristo e se celebra o mistério da Ceia do Senhor "para que o corpo da inteira fraternidade seja unido por meio da carne e sangue do Senhor». Em qualquer comunidade que participa do altar sob o ministério sagrado do Bispo, é manifestado o símbolo do amor e da unidade do Corpo místico, sem o que não pode haver salvação. Nestas comunidades, embora muitas vezes pequenas e pobres, ou dispersas, está presente Cristo, por cujo poder se unifica a Igreja una, santa, católica e apostólica. Pois «outra coisa não faz a participação no corpo e sangue de Cristo, do que transformar-nos naquilo que recebemos. (LUMEN GENTIUM 26). 
O decreto Presbyterorum ordinis, por sua parte, tratando longamente do munus regendi dos presbíteros, conclui dizendo:

Uma comunidade cristã não pode formar-se senão tendo como raiz e como centro a celebração da santíssima Eucaristia, na qual deve inspirarse toda a educação ao espírito comunitário. A celebração eucarística, por sua vez, para ser sincera e plena deve conduzir seja às diversas obras de caridade e à recíproca ajuda, seja à ação missionária e às várias formas de testemunho cristão. (PRESBYTERORUM ORDINIS 6, 5).

\section{A igreja faz a eucaristia: sujeito integral da ação litúrgica}

A esta altura, porém, surge a questão: "quem faz [celebra] a Eucaristia”? A esta pergunta a resposta unânime, quer nos textos do Novo Testamento, quer nos textos dos primeiros escritores cristãos, é clara: a Igreja. "Antes de mais nada, a ceia do Senhor é um ato da comunidade inteira: seja qual for a sua condição social, os fiéis se reúnem regularmente para uma ceia fraterna" (DUFOUR, 1984, p. 24). A Igreja, ou comunidade cristã - de acordo com estudo bastante conhecido de Congar - é o sujeito integral de toda ação litúrgica (CONGAR, 1969, p. 279-338).

\subsection{A assembleia toda}

De fato, escrevendo aos coríntios, Paulo dirige-se à comunidade toda. Não só no cabeçalho (1Cor 1,1-2), mas, especificamente, quando fala da Eucaristia, onde abundam os pronomes "nós" (1Cor 10,14-22) e "vós", "vos", "vossos", "vossas" (1Cor 11,17-34), relativos aos "bem-amados" reunidos "em Igreja" (1Cor 11,18).

Muito bem: quem faz [celebra] a eucaristia é a comunidade congregada para tal fim. Se é a comunidade, quer isso dizer que todos fazem tudo e tudo da mesma maneira? Há alguém que preside a celebração da eucaristia nas comunidades paulinas? Há algum presidente fixo, ou a presidência passa de mão em mão, num sistema de rodízio? A presidência da eucaristia obedece a algum princípio institucional ou é entregue àquele que, na ocasião, manifestar destreza para tanto? Afinal, o que dizem os escritos paulinos a respeito? E o restante do Novo Testamento? 
Em Paulo, não se encontra nenhuma palavra sobre a presidência da ceia do Senhor. De 1Cor 11 se deduz que, naquela Igreja, se celebrava a ceia do Senhor também estando Paulo ausente, mas não se diz se havia um ofício de presidência e quem o exercesse.

O mesmo se pode dizer do restante do Novo Testamento:

Sobre a presidência da ceia do Senhor, o Novo Testamento não é explícito, ainda que as narrações sinóticas sublinhem que, na última ceia, Jesus estava "com os Doze" (Mt 26,20; Mc 14,17; Lc 22,14 - apóstolos = Doze) e, portanto, só eles receberam o mandamento: "Fazei isto em memória de mi” (Lc 22,19; 1Cor 11,24.25)”. (CATTANEO, 1997, p. 205).

Neste sentido, há a convicção de que, estando presente um apóstolo, caberia a ele a presidência, o que a celebração da fração do pão em Trôade confirmaria (At 20,7-12).

O formato da ceia familiar judaica festiva - sobre o qual se calcou a fração do pão cristã - parece decisivo para resolver esta questão. (DUFOUR, 1984, p. 29) Nestas ceias rituais, cabia ao chefe da casa (ou a um hóspede ilustre) a presidência. Comentando 1Cor 14,16 ("Se deres graças apenas com teu espírito, como poderá o ouvinte não iniciado dizer 'Amém' à tua ação de graças, visto que não sabe o que dizes?”), observa Perrot: "Ainda que a celebração da "ceia do Senhor" seja comunitária, parece haver uma distinção entre "todos" e "algum" (ou "alguns"): "Note-se, neste caso, a distinção feita entre os costumes judaicos, entre os que recitam as orações 'eucarísticas' e os que as convalidam." (através do "Amém”) (PERROT, 2005, p. 77)

\section{2 "Quem preside a comunidade preside a Eucaristia"}

Pode-se fundadamente dizer que, também na Igreja primitiva, quem presidia a Igreja local presidia também a Eucaristia da comunidade (LEGRAND, 1977, p. 409-431). Segundo a Apologia I de Justino, escrita em torno dos anos 150160, a presidência da eucaristia compete ao "proestós ton adelphôn" (aquele que é preposto aos irmãos), o qual, depois da leitura das memórias dos apóstolos e dos 
escritos dos profetas (por um leitor), e da homilia (feita também pelo presidente), trazidos o pão, o vinho e a água, "eleva súplicas e ações de graças com toda a sua capacidade" (JUSTINO. 1 Apologia 67,3-7). Tertuliano (160-225) informa que "o sacramento da eucaristia nós o recebemos da mão de nenhum outro senão daqueles que presidem (praesidentium)" (TERTULIANO, De corona militum c. 3).

Na Igreja de Antioquia da Síria - fundada por judeu-cristãos fugidos da perseguição em Jerusalém quando do martírio de Estêvão (At 8,1-3; 11,19.26) segundo o testemunho de Inácio (+ 107 circa), há um bispo, um presbitério e alguns diáconos, cabendo ao bispo, rodeado pelos presbíteros e diáconos, presidir a eucaristia (Efe 20,2), que deve ser única (Fil 4,1) e não pode ser celebrada sem o bispo: "Por legítima seja tida tão-somente a Eucaristia, feita sob a presidência do bispo ou por delegado seu". (Esm 8,1).

Essa foi a regra geral nos primeiros séculos: quem preside a Igreja preside a sua Eucaristia. Não no sentido em que ele celebra, e os demais assistem passivamente. Mas no sentido em que todos são solidariamente responsáveis pela comunidade local, ainda que não da mesma forma e ao mesmo título; no sentido em que os ministros são parceiros, companheiros, partners dos cristãos leigos e leigas, mas diferentes deles porquanto não só estão na Igreja, mas são seus presidentes, guias, pastores; o "nós" que o presidente da eucaristia frequentemente usa não é um plural majestático, mas o "nós" que é a assembleia da qual ele faz parte e que ele representa.

A Eucaristia, de fato, era celebrada por toda a assembleia, estruturada ministerialmente, sob a presidência do bispo ou - a partir do surgimento das paróquias, no século IV - também de um presbítero. Esta foi a prática e a consciência compartilhadas no período patrístico e, de modo geral, em toda a Alta Idade Média (da metade do século $\mathrm{V}$ à metade do século $\mathrm{X}$, aproximadamente). Alguns perigos, porém, rondam esta prática. 
A reviravolta pela qual passou a compreensão da eucaristia em período carolíngio (grosso modo, séculos IX e X), entretanto, repercutiu também na celebração da Eucaristia. Aquelas inovações na compreensão da eucaristia vieram acompanhadas por uma crescente separação entre o clero e os demais fiéis. É bom lembrar que, já por volta do século III, dera-se aquilo que Alexandre Faivre chama de ereção de uma "barreira institucional” (FAIVRE, 1986, p. 61, 93) entre clero e leigos, acentuando-se, por um lado, a distinção entre ministros ordenados e leigos, o que redundou num crescente distanciamento entre sacerdotes e leigos e, “ $a$ fortiori”, leigas, na celebração da Eucaristia; 6 pelo outro, assiste-se a uma divinização dos ministros ordenados, particularmente do bispo, o que, a médio e longo prazo, levou a um esvaziamento teológico e prático dos leigos. O que Tertuliano definiu no início do III $^{\circ}$ século (leigo = non clericus) deu seu amargo fruto no século IX:

A separação entre o altar e o povo, entre os clérigos e os leigos, entre os portadores da plenitude do sacerdócio e a comunidade - esta separação, que pertence à essência mesma da Igreja, nunca foi esquecida - tende a tornar-se cada vez mais evidente, e pode-se falar mesmo de uma barreira entre os dois (JUNGMANN, 1951, p. 116).

Vários elementos contribui para tanto: a manutenção do latim na liturgia, apesar de ser compreendido apenas por uma parte do clero e da aristocracia; a colocação do altar contra a parede, ao fundo da ábside; o deslocamento da cátedra episcopal para o lado direito da ábside; a tribuna vai se transformando num verdadeiro muro de separação entre o coro reservado aos sacerdotes e a nave da igreja.

\footnotetext{
${ }^{6}$ A Didascalia dos Apóstolos (obra pseudoepígrafa das últimas décadas do século III) é pouco estudada entre nós. Mas é um importante documento para se perceber o lugar central - uma espécie de monarca absoluto! - que o bispo ocupa na comunidade: "Portanto, assim como não era permitido ao estrangeiro, isto é, àquele que não era levita, aproximar-se do altar ou fazer uma oferta sem o sumo sacerdote, assim vós não fareis nada sem o bispo. Se alguém fizesse alguma coisa sem o bispo, o faria em vão, porque não Ihe seria reconhecido como um trabalho. De fato, não convém fazer nada sem o príncipe dos sacerdotes. Levai, portanto, os vossos dons ao bispo ou diretamente ou através da mediação dos diáconos e, quando os tiver recebido, os distribuirá com justiça." (DIDASCALIA II, 27, 1-3).
} 
Esta divisão, este muro, entre povo e clérigos no culto público da Igreja - "a chaga da mão esquerda da santa Igreja”, segundo Rosmini (ROSMINI, 1968, p. 3955) - perdurou oficialmente até a segunda metade do século XX e ainda não se desfez totalmente.

\subsection{Em comunhão com a Igreja local e a comunhão universal das Igrejas}

Entretanto, graças a um conjunto de ideias e movimentos - no nosso caso, sobretudo o movimento litúrgico - que convergiram no Concílio Vaticano II, a presidência da eucaristia só pode ser vista “na” Igreja e "a serviço" da Igreja, concretamente, a assembleia dos fiéis (christifideles), que é o verdadeiro sujeito da ação litúrgica. É suficiente a afirmação de Sacrosanctum Concilium 26: "As ações litúrgicas não são ações privadas, mas celebrações da Igreja, que é o "sacramento da unidade”, isto é, o povo santo, unido e ordenado sob a direção dos bispos.7 Por isso, estas celebrações pertencem a todo o Corpo da Igreja, e o manifestam e afetam; mas tocam (attingunt) a cada a cada um dos membros de modo diferente, conforme a diversidade de ordens, ofícios e da participação atual” (SACROSANCTUM CONCILIUM 26). 8 Daí decorrem a preferência pela celebração comunitária (SACROSANCTUM CONCILIUM 27), o princípio segundo o qual, "nas celebrações litúrgicas, cada qual, ministrou fiel, no desempenho de sua função, faça tudo e só aquilo que pela natureza da coisa ou pelas normas litúrgicas lhe compete" (SACROSANCTUM CONCILIUM 28), os ministérios litúrgicos nãoordenados (SACROSANCTUM CONCILIUM 29), as expressões típicas da participação ativa dos fiéis (SACROSANCTUM CONCILIUM 30), inclusive prevendo-as nas rubricas dos novos livros litúrgicos (SACROSANCTUM CONCILIUM 31), a desautorização de qualquer acepção de pessoas na liturgia

\footnotetext{
${ }^{7}$ Convém lembrar que o próprio Concílio de Trento, no Decreto sobre a Missa, ensina: “Celebrada, de fato, a Páscoa, que a multidão dos filhos de Israel imolava em recordação da saída do Egito (Ex 12), [Jesus] instituiu a nova Páscoa, isto é, a si mesmo, que devia ser imolado pela lgreja por meio dos seus sacerdotes sob sinais visíveis, em memória da sua passagem deste mundo ao Pai, quando nos redimiu com a efusão do seu sangue, nos “libertou do poder das trevas e transferiu no seu reino" (Cl 1,13)." (DH 1741).

8 "Não se pode captar o verdadeiro alcance desta afirmação (de per si muito tradicional) se não levando em conta o contributo que veio progressivamente do Movimento litúrgico, no interior do qual diversos autores procuraram recuperar a dimensão eclesial do culto, não só como afirmação de princípio, mas também como exigência de envolvimento de todos os fiéis na ação litúrgica. Tra tava-se de reaproximar ativamente os fiéis daquela liturgia que, ao longo dos séculos, se tornara geralmente prerrogativa dos ministros sacros ou dos monges, substituída com orações de tipo devocional." (GIRARDI, 2014, p. 140).
} 
(SACROSANCTUM CONCILIUM 32), o uso do vernáculo (SACROSANCTUM CONCILIUM 36), etc.

Evidentemente, para encontrar sua plena legitimação teológica, o princípio enunciado em Sacrosanctum Concilium 26 tinha que se articular com o conjunto da renovação da eclesiologia. Com efeito, não basta dizer que a liturgia é celebração da Igreja; é necessário especificar que a Igreja é uma realidade unitária - uma comunhão -, que todos os membros compartilham o seu ser, a sua edificação, a sua missão. Em outras palavras: são sujeitos! Neste sentido, Sacrosanctum Concilium 26 deve ser lido no horizonte de Sacrosanctum Concilium 14, pois o verdadeiro sujeito da ação litúrgica é a ecclesia, a assembleia doas fiéis oferecendo pelo ministério dos sacerdotes, como já o ensinara Trento.

Está aí o fundamento da reforma litúrgica, que visa, de um lado, a restituir sua verdade às celebrações e, do outro lado, a promover a participação dos fiéis. São eles, é a ecclesia, ela mesma compreendida, na linha dos Padres, como o "nós" dos cristãos. (CONGAR, 1967, p. 88).

O direito-dever dos fiéis de participar na liturgia tem seu fundamento no batismo, portanto, na condição cristã comum a todos os membros do povo de Deus. A Lumen gentium, por sua vez, desenvolverá uma visão de Igreja como povo de Deus, segundo a qual "ainda que alguns por vontade de Cristo sejam constituídos mestres, dispensadores dos mistérios e pastores em benefício dos demais, reina, contudo, entre todos verdadeira igualdade quanto à dignidade e ação comum a todos os fiéis na edificação do Corpo de Cristo. Porquanto a distinção que o Senhor estabeleceu entre os ministros sacros e o restante do Povo de Deus traz entre si uma verdadeira união" (LG 32). Neste contexto, ganha toda sua relevância os nn. 10 e 11 da mesma Lumen gentium sobre o sacerdócio comum e sua expressão nos sacramentos, respectivamente.

A liturgia, portanto - especialmente a eucaristia - pertence a todo o corpo da Igreja, o manifesta e o implica (SACROSANCTUM CONCILIUM 2). Cada fiel está envolvido e se reconhece nela. Contudo, "não se deve temer que isto signifique uma anulação das distinções ministeriais. De fato, cada membro da comunidade 
participa da mesma ação litúrgica segundo a própria condição e função ministerial. A unidade orgânica da comunidade que celebra contém as diferenças dos ministérios, impedindo que cada um pretenda esgotar em si a realidade da Igreja a ponto de desautorizar os outros na realização das ações litúrgicas” (GIRARDI, 2014, p. 141).

Tratando-se de todo o corpo da Igreja, o ministério pastoral - que, a seu modo, sucede o ministério dos apóstolos - tem que estar necessariamente presente. A eucaristia só pode ser presidida por um bispo ou por um presbítero; sem a presidência de um bispo ou de um presbítero não existe Eucaristia. A Lumen gentium, falando do múnus episcopal de santificar, afirma: "O bispo, distinguido pela plenitude do sacramento da Ordem, é o "administrador da graça do sacerdócio supremo”, mormente na Eucaristia, que ele mesmo oferece ou cuida que seja oferecida, e pela qual a Igreja vive e cresce.” (LUMEN GENTIUM 26,1) Mais adiante, falando dos presbíteros, diz: "Cristo, a quem o Pai santificou e enviou ao mundo (Jo 10,36), fez os bispos participantes de Sua consagração e missão, através dos Apóstolos, de quem são sucessores. Os bispos passaram legitimamente o múnus do seu ministério, em grau diverso, a pessoas diversas na Igreja. Assim, o ministério eclesiástico, divinamente instituído, é exercido em diversas ordens pelos que desde a antiguidade são chamados bispos, presbíteros e diáconos. Embora os presbíteros não possuam o ápice do pontificado e no exercício de seu poder dependam dos bispos, estão, contudo, com eles unidos na dignidade sacerdotal” (LUMEN GENTIUM 26 a). Os diáconos, contudo, como ensina Lumen gentium 29, recebem a imposição das mãos “não para o sacerdócio, mas para o ministério". 9

Numa palavra, a Igreja que faz a Eucaristia é a Igreja toda, reunida em assembleia eucarística, presidida por um bispo ou um presbítero, para que $a$ Eucaristia faça a Igreja:

\footnotetext{
${ }^{9}$ Sabe-se que o texto está truncado. No original, se lê: "Na ordenação do diácono, só o bispo impõe as mãos porque o diácono não é ordenado para o sacerdócio, mas para o serviço do bispo: para fazer o que lhe é por este determinado". (Tradição Apostólica 23, 1520). Nos Statuta Ecclesiae Antiqua (editado na Gália em torno do ano 475), falta a parte final: "Quando é ordenado um diácono, só o bispo, que o abençoa, imponha a mão sobre a sua cabeça, pois é consagrado não para o sacerdócio (non ad sacerdotium), mas para o ministério (sed ad ministerium)" (MUNIER, 1963, p. 148, 181).
} 
"a fim de que, comendo e bebendo o corpo e o sangue do Senhor, toda a fraternidade se uma intimamente". Em toda comunidade de altar unida para o sacrifício, sob o ministério sagrado do bispo, manifesta-se o símbolo daquela caridade e "unidade do corpo místico, sem a qual não pode haver salvação". Nestas comunidades, embora pequenas e pobres, ou vivendo na dispersão, está presente Cristo, por cuja virtude se consocia a Igreja uma, santa, católica e apostólica. Pois "a participação do corpo e do sangue de Cristo não faz outra coisa senão transformar-nos naquilo que tomamos". (LUMEN GENTIUM 26).

O Documento Preparatório tem plena consciência da complexidade da questão. Aliás, quando toca no assunto das comunidades sem acesso à celebração frequente da Eucaristia, vai distinguindo os vários níveis da questão:

A Assembleia Especial para a Região Pan-Amazônica precisa de um grande exercício de escuta recíproca, que se faça especialmente entre o Povo fiel e as autoridades do magistério da Igreja. E um dos pontos principais a ser escutado será o lamento «de milhares dessas comunidades desprovidas (carentes) da Eucaristia dominical por longos períodos» (DOCUMENTO DE APARECIDA 100e). (SÍNODO PARA A AMAZÔNIA, n. 64).

Mais adiante, se lê: "Nesse sentido, o Vaticano II nos lembra que todo o povo de Deus participa do sacerdócio de Cristo, embora distinguindo sacerdócio comum do sacerdócio ministerial (LG 10)" (SÍNODO PARA A AMAZÔNIA, n. 81)

Partindo daí, urge avaliar e repensar os ministérios que hoje são necessários para responder aos objetivos de uma Igreja com "rosto amazônico" e uma Igreja com "rosto indígena". Textualmente:

Uma prioridade é [...] definir os conteúdos, métodos e atitudes para se constituir uma pastoral inculturada, capaz de responder aos grandes desafios no território. Outra é [...] propor novos ministérios e serviços para os diferentes agentes de pastoral que respondem pelas tarefas e responsabilidades da comunidade. Nessa perspectiva, é preciso identificar o tipo de ministério oficial que pode ser conferido à mulher, levando em conta o papel central que hoje desempenham as mulheres na Igreja amazônica. Também é necessário [...] promover o clero indígena e os que nasceram no território, afirmando sua própria identidade cultural e seus valores. Finalmente, é preciso repensar novos caminhos para que o Povo de Deus tenha melhor e frequente acesso à Eucaristia, centro da vida cristã. (DOCUMENTO DE APARECEIDA 251) (SÍNODO PARA A AMZÔNIA, n. 81). 
E, após as reflexões feitas no documento, vem, na Parte III do Documento Preparatório, uma série de questões para facilitar a escuta das realidades da região amazônica. Entre elas: "A seu ver, quais são os serviços e os ministérios com rosto amazônico que deveriam ser criados e promovidos?”

\section{Que presbíteros para qual igreja? A questão dos modelos}

Não vamos abordar aqui - nossa conversa já vai longa - o perfil concreto que, a nosso ver, deveria ter o futuro presidente de comunidade, que, devidamente ordenado presbítero, por presidir a comunidade, poderá e deverá também presidir a celebração da eucaristia da comunidade. Só uma palavrinha prévia: estas duas funções "presidir a comunidade" e "presidir a Eucaristia" merecem uma reflexão especial - que também não vamos fazer aqui - inclusive porque é legítimo visualizar prospectivamente modelos diferentes de concebê-las e de exercê-las. Ou negativamente: os eventuais futuros presbíteros de comunidade (chamemo-los assim) não deveriam replicar o modelo hegemônico dos párocos atuais, que respondem pela administração da paróquia em todos os aspectos, desde questões patrimoniais, financeiras, pastorais, sacramentais e outras, até à (escandalosamente mínima) atenção, acolhida, acompanhamento, counseling dos fiéis individuais. Mas isso ficará para outro texto.

Proponho, aqui, três questões que me parecem básicas para concluir a reflexão que fizemos até aqui e poder introduzir elementos novos em ulteriores estudos.

\subsection{Comunidades têm homens aptos à ordenação presbiteral}

Nas comunidades, homens e mulheres, às vezes jovens, mas de modo geral adultos, assumem os mais diversos serviços e ministérios. São animadores de Grupos de Jovens, responsáveis pela Promoção Humana, líderes da Pastoral da Criança, pessoas dedicadas à Pastoral da Saúde, coordenadores de Círculos 
Bíblicos (em alguns lugares, Grupos de Reflexão ou Grupos de Vivência), missionários, visitadores, promotores do Dízimo, responsáveis pela Economia e Finanças da comunidade, catequistas, equipes de celebração (comentaristas, leitores, salmistas, cantores, acólitos, instrumentistas, presidentes) e serviço de Liturgia, presidentes de Celebrações da Palavra, animadores de Comunidades (seja Comunidades Eclesiais de Base seja Setores ou Comunidades semelhantes dentro da paróquia ou referidas diretamente à Diocese) (ALMEIDA, 1989, p. 17-89; ALMEIDA, 2013).

Nessas comunidades, o Espírito tem sido generoso, e "a cada um é dado um dom do Espírito para utilidade comum" (1Cor 12,7). Mesmo assim, elas não têm um presbítero próprio e permanente para presidi-las e, consequentemente, para presidir a celebração da Eucaristia. Na Igreja primitiva e na Igreja antiga, esta situação anômala absolutamente não existiria: "Não havia Igreja sem Eucaristia e não havia Eucaristia sem bispo" (CATTANEO, 1997, p. 96) e, mais tarde, com o surgimento das paróquias, sem presbítero.

Será que ninguém, nessas comunidades, teria vocação para assumir o ministério presbiteral? Será que o Espírito Santo que, na Igreja de Corinto, distribuiu, entre seus membros, os dons mais variados, de modo que ela tivesse tudo o que lhe era necessário para ser Igreja e para realizar a missão (1Cor 12,411.28-30) - inclusive a celebração da eucaristia (1Cor 11) - nos dias atuais, não está agindo da mesma maneira? Estaria o Espírito dando alguns dons, mas não todos? Por que dá dons que nem seriam tão necessários, e deixaria de dar outros que são essenciais para a Igreja ser plenamente Igreja? Por que, nos últimos tempos, as vocações para o presbiterado só aumentam em alguns países da África e em parte da Ásia? “A direita do Altíssimo mudou” (Sl 77,11)?

O problema não está, evidentemente, do lado de Deus, mas do nosso, que, em relação a esta questão da falta - em muitos lugares, crônica; em algumas áreas, relativa; em outras, absoluta - de ministros ordenados para a presidência da eucaristia nas comunidades, não temos sido capazes como Igreja de ver e 
interpretar os "sinais dos tempos" (GS 4) e de voltar ao essencial em matéria de ministério presbiteral, voltando à praxe da Igreja nascente, da Igreja antiga e muito além: Nenhuma comunidade sem Eucaristia, nenhuma Eucaristia sem comunidade. Nenhuma comunidade sem seu ministro ordenado, nenhum ministro ordenado sem sua comunidade! ${ }^{10}$ Liberada de condicionantes ao acesso ao ministério presbiteral que, sob certos aspectos e em determinados contextos, podem ser considerados convenientes, mas jamais em si necessários e universalmente exigíveis, a Igreja se colocaria em melhores condições para selecionar bons candidatos - entre jovens e adultos, solteiros e casados, com formação universitária e sem - ao ministério presbiteral.

O bispo emérito de Aliwal, na África do Sul, Fritz Lobinger, não sugere meramente a ordenação de "viri probati", mas a ordenação de homens, solteiros ou casados, em comunidades que tenham uma boa caminhada eclesialcomunitária, dotadas de serviços e ministérios não-ordenados nos vários âmbitos da vida e da missão da Igreja (palavra - culto - caridade), cujos membros e lideranças estejam tendo acompanhamento e formação adequada às suas necessidades pessoais, familiares, pastorais e missionárias: "communitates probatae"! Caberia à própria comunidade, integrada, evidentemente, na Igreja local, com seu presbitério e seu bispo diocesano, a escolha daqueles que, uma vez ordenados para o presbiterado, presidiriam a comunidade e, consequentemente, a eucaristia da comunidade.

Não temos dúvida de que, também na região amazônica, há comunidades maduras ("communitates probatae") e há homens maduros ("viri probati") em condição de ser chamados e ordenados para assumirem o ministério presbiteral nestas mesmas comunidades.

\footnotetext{
${ }^{10}$ É importante esclarecer que "a comunidade não precisava ser grande para ter um bispo e um grupo de presbíteros - um presbitério - à sua frente. Ela precisa ser consciente e dinamicamente cristã [...]. Uma comunidade com um mínimo de doze famílias cristãs podia, no século II, ter um bispo!" (LOBINGER, 2008, p. 9). Dizem os historiadores Fliche e Martin: "Cada comunidade, por simples que tenha sido sua constituição na época primitiva, tinha desde o início os elementos essenciais de uma real organização. Um conselho de presbíteros ou anciãos [...]" (FLICHE; MARTIN, 1946, p. 375).
} 


\title{
4.2 A questão do celibato: carisma e lei
}

Em relação ao celibato, é preciso distinguir com toda a clareza o "carisma" do celibato (que é um dom da graça e uma opção pessoal) e a lei do celibato (estabelecida pela Igreja), como o reconhece o próprio decreto Presbyterorum ordinis:

\begin{abstract}
De si, não é exigida pela própria natureza do sacerdócio, como se deixa ver pela prática da Igreja primitiva e pela tradição das Igrejas orientais, onde, além daqueles que, com todos os Bispos, escolhem, pelo dom da graça, a observância do celibato, existem meritíssimos presbíteros casados. Recomendando o celibato eclesiástico, este sagrado Concílio de forma nenhuma deseja mudar a disciplina contrária, legitimamente vigente nas Igrejas orientais, e exorta amorosamente a todos os que receberam o presbiterado já no matrimônio, a que, perseverando na sua santa vocação, continuem a dispensar generosa e plenamente a sua vida pelo rebanho que lhes foi confiado. (PRESBYTERORUM ORDINIS 16,1).
\end{abstract}

Não é o carisma do celibato que está em discussão; o que pode ser discutido é a lei do celibato. Em primeiro lugar, por se tratar de uma questão disciplinar, não teológica. Em segundo lugar porque, ainda que a conveniência do celibato para os ministérios ordenados seja múltipla (SACERDOTALIS CAELIBATUS 18), aspectos desta conveniência, em determinados circunstâncias, podem ser razoavelmente questionados. O Papa Paulo VI tinha clara consciência dos questionamentos atuais ao ponderar (e descartar) as objeções ao celibato e à lei do celibato: vocação ao ministério e vocação ao celibato são vocações distintas; o drama da preocupante escassez de clero; as sombras sobre a vivência do celibato; o conflito entre o celibato e o instinto sexual; a formação inadequada dos futuros padres para a vida celibatária, etc. ( $\mathrm{SaC}$ 5-11). Aliás, não dá para entender - desculpem a expressão que uma ou algumas disposições disciplinares que não são intrínsecas ao ministério sacerdotal se sobreponham, na prática eclesial, ao direito-dever dos fiéis de celebrar a Eucaristia, num evidente conflito - em regiões inteiras e em situações concretas em que se dá uma falta absoluta (ou quase) de sacerdotes entre um "direito de legislação" e o "direito da graça." (HOFFMANN, 1968, p. 645676). 
O eclesiólogo Legrand, valendo-se de um estudo clássico do canonista alemão Hans Dombois (1907-1997), preconiza a necessidade de sério discernimento eclesial quando o "direito de legislação" passa a comprometer o "direito da graça":

Uma delicada questão de ajustamento entre estes dois direitos seria colocada se prescrições relativas ao estado de vida dos padres (enquadradas, portanto, no direito de legislação) viesse a comprometer o direito sacramental. Estar-se-ia diante de uma situação deste gênero, parece-nos, se a deficiência do número de cristãos capazes de viver o celibato, desde que estando aptos à ordenação, viesse a privar a Igreja deste ou daquele país dos padres necessários aos quais os cristãos têm direito, sem que a solidariedade de outras Igrejas locais pudesse remediar os graves danos que daí resultariam para a vida cristã. Repetimo-lo: não se trata de colocar em causa a necessidade e os méritos de um direito de legislação, mas convém que seja sempre regulado pelo direito da graça. Quando se abstém deste discernimento e o direito de legislação toma um lugar dominante, então racionalismo abstrato e legalismo arriscam de prevalecer sobre a graça do Evangelho e sobre a sua liberdade. (LEGRAND, 1979, p. 139-172).

Enfim, Igreja poderia, para o Ocidente, seja acolher a praxe oriental onde convivem um clero celibatário e um clero casado (UNITATIS REDINTEGRATIO 16; SACERDOTALIS CAELIBATUS 15) seja abrir exceções, como já ocorre em alguns casos, ou conceder dispensas da lei geral. Em algumas entrevistas (por exemplo, ao jornal Die Zeit em 2017, ou na volta da Jornada Mundial da Juventude de 2019), o Papa Francisco já se mostrou aberto a analisar essas alternativas.

\subsection{A ordenação presbiteral de mulheres}

A questão da ordenação de mulheres ao sacerdócio (entendendo-se episcopado e presbiterado) - não ao diaconato, que já houve na Igreja por séculos - é diferente da questão do celibato. É um fato, não só no Brasil, que as mulheres

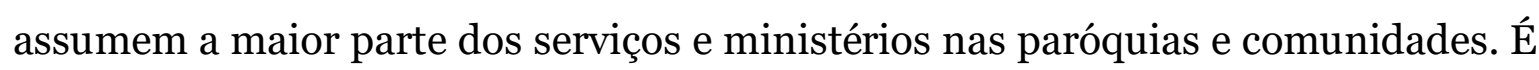
sabido também que a ordenação de mulheres é uma demanda que tem crescido, sobretudo em áreas culturalmente mais liberais, mas não só: “As reivindicações dos legítimos direitos das mulheres, a partir da firme convicção de que homens e mulheres têm a mesma dignidade, colocam à Igreja questões profundas que a desafiam e não se podem elidir superficialmente." (EVANGELII GAUDIUM 104). 
O Papa Francisco, porém, tem declarado que esta porta está fechada. ${ }^{11}$ Portanto, na conjuntura atual, o sacerdócio continuará reservado a pessoas do sexo masculino; consequentemente, nenhum remédio à escassez de sacerdotes deve ser buscado na direção da eventualidade da ordenação das mulheres. Isto, contudo, não pode querer dizer que não se possam examinar os múltiplos argumentos alegados pelo magistério pontifício, especialmente o peso das 'opções' hermenêuticas prévias que as fundamentam, seja em nível do estatuto da Tradição, seja em nível da argumentação bíblica, seja em nível teológico (BORRAS, 2017, p. 189-193). Afinal, ninguém está proibido de bater à porta fechada!

\subsection{Ouvir sinodalmente o santo povo fiel de Deus}

É preciso encontrar - e sem mais delonga, pois a demora na Amazônia já leva quatro séculos (LUGON, 1977, p. 245; MURATORI, 1754, p. 145, 148) alguma solução para a situação das dezenas de milhares de comunidades sem celebração regular da Eucaristia, e esta solução precisa ser buscada por todos.

Não se trata de uma reivindicação de democracia na Igreja nem de pautar as decisões eclesiais pelo critério da maioria. (Ainda que a Igreja possa aprender muito com a democracia). O que está em jogo é muito mais que isso: a condição cristã comum a todos os membros da Igreja, dada pelo batismo, que confere a todos os fiéis uma dignidade única, uma habilitação à participação na missão sacerdotal, régia e profética de Cristo e no sentido sobrenatural da fé de todo o povo de Deus.

A consciência deste estatuto ontológico do povo cristão se exprimiu, nos primeiros anos do cristianismo, entre outras coisas, numa participação ativa das comunidades em decisões importantes como a eleição de Matias para ocupar a vaga deixada por Judas (At 1,15-26), a decisão de dotar a parte helenista da Igreja de alguns profetas e doutores da Igreja de Antioquia para a evangelização dos gentios (At 13,1-3) e a controvérsia sobre a circuncisão dos gentios (At 15).

\footnotetext{
${ }^{11}$ Ver Congregação para a Doutrina da Fé, "Declaração sobre a questão da admissão das mulheres ao sacerdócio ministerial Inter insigniores" (15 de outubro de 1976: DC 74 (1977), p. 158-164; João Paulo II, Ordinatio Sacerdotalis (22 de maio de 1994).
} 
Nos dias atuais, em que se ressaltam o "sensus fidei" e o "sensus fidelium", e em que o Papa Francisco insiste na prática da "sinodalidade", acreditamos que a questão da ordenação presbiteral de líderes de comunidades, casados ou solteiros, deva ser debatida por todos os fiéis, especialmente pelas comunidades que vivem uma situação de escassez relativa ou absoluta de presbíteros.

O tema mal aflorou no Sínodo sobre "Os jovens, a fé e o discernimento vocacional" (2018), mas tem que ser colocado e debatido com toda a clareza, a franqueza e a profundidade no Sínodo para a Amazônia (2019). As Igrejas locais da Amazônia têm o direito e o dever de buscar uma Igreja com rosto amazônico, o que implica ter ministros próprios com um perfil adequado às suas condições sociais, culturais e religiosas específicas.

Um elemento constitutivo da sinodalidade é a escuta. A hierarquia tem que ouvir, sobretudo quando se trata de situações e questões vividas em primeira pessoa pelos fiéis leigos e leigas: família, vida conjugal, educação dos filhos, vida profissional, etc. A vida vivida da hierarquia e dos leigos e leigas é outra, a ótica e o horizonte muito distintos, as preocupações são muito diferentes, condicionando seja a abordagem seja os resultados. No caso que nos ocupa aqui, a falta de presbíteros e de celebração da eucaristia em muitas comunidades afeta de maneira muito diferente os bispos de uma conferência episcopal, o bispo local, o padre que só pode passar pela comunidade uma vez por ano, e os que insistem em ser católicos neste deserto pastoral e sacramental.

Temos que ouvir o povo, temos que aprender a ouvir o povo, temos que aprender com o povo, temos que elaborar com o povo as decisões pastorais (e outras), mesmo que, ao cabo, por direito, competir aos bispos e, entre eles, ao papa, tomar a decisão final.

O adágio medieval continua válido, não por ser antigo, mas por ser sábio: "Quod omnes tangit ab omnibus tractari debet" (o que afeta a todos deve ser tratado por todos)! 


\subsection{Papel dos ministros ordenados atuais}

Os padres atuais não precisam temer a chegada dos padres comunitários. Ao contrário. Têm uma importância e um papel decisivo nesta hora, no sentido de: a) intensificar o processo de implementação e consolidação de comunidades de tamanho humano em suas áreas de atuação; b) fortalecer a presença de ministérios não-ordenados nas comunidades; c) dar prioridades à formação das pessoas e dos grupos ativos nas comunidades, especialmente animadores de comunidades e coordenadores de serviços e pastorais; d) aprofundar a reforma litúrgica promovida pelo Concílio, visando à participação ativa, consciente e frutuosa especialmente na eucaristia, de modo que a eucaristia seja, também experiencialmente, fonte e cume da vida cristã, da evangelização e da Igreja.

Se a Igreja abrir a porta para a ordenação presbiteral de líderes comunitários, solteiros ou casados, os padres atuais passarão a ter uma responsabilidade ainda maior, não só em relação à diocese toda, mas, particularmente, em relação ao acompanhamento, à animação, à formação dos padres de comunidade. Vem-me à mente aquela passagem de Atos, onde se lê que "os apóstolos [Paulo e Barnabé] designaram anciãos para cada Igreja e, com orações e jejuns, os confiavam ao Senhor, em quem tinham passado a crer" (At 14,23) e aquela outra em que Paulo diz a Barnabé: "Voltemos para visitar os irmãos em cada cidade onde anunciamos a palavra do Senhor, para ver como estão" (At 15,36), e ainda aquela em que Paulo, "percorrendo a Síria e a Cilícia, ia confirmando as igrejas." $(15,41)$. Mais do que hoje, talvez, as comunidades locais e seus ministros ordenados vão precisar que os padres atuais - em criativa itinerância - passem "para ver como estão" e para se sentirem "confirmadas" em sua nova caminhada.

Os bispos têm uma responsabilidade única neste processo, uma vez que depende deles não só preparar suas Igrejas para que surjam vocações para padres comunitários, mas também, individualmente ou como conferência, pleitear a 
dispensa da norma do celibato em vista do bem das comunidades habitualmente desprovidas da celebração da eucaristia por falta de padres.

Um canonista de primeira grandeza, Alphonse Borras, afirma que, sem pôr em causa a lei do celibato, a autoridade competente pode dispensar desta regra, em função das comunidades sem presbíteros (BORRAS, 2002, p. 17-18). Com efeito, "a dispensa, ou relaxação de uma lei meramente eclesiástica num caso particular, pode ser dada pelos que têm poder executivo dentro dos limites de sua competência" (can. 85). O bispo diocesano, considerando o bem espiritual dos fiéis, "pode dispensá-los das leis disciplinares, universais ou particulares, dadas pela suprema autoridade da Igreja para o seu território ou para seus súditos" (can. 87). Não deve fazê-lo "sem causa justa e razoável, levando-se em conta as circunstâncias do caso e a gravidade da lei, da qual se dispensa" (can. 90). Tratarse-ia, concretamente, raciocina Borras, de obter que a Santa Sé conceda às Conferências Episcopais o poder de dispensar do impedimento do can. 1042, § 1, relativo aos homens casados (viri uxorem habentes). O poder atual de dispensa da Santa Sé é, a rigor, uma reservação ("reservatio") (can. 1047, parágrafos 2 e 3). Ou seja:

Isto significa, com toda a probabilidade, que, por sua própria natureza, a dispensa cabe aos Ordinários. Sem atribuir, contudo, este poder a cada bispo diocesano, poder-se-ia alargar esta reservatio às Conferências episcopais, que poderiam judiciosamente e oportunamente conceder esta dispensa a pedido dos bispos diocesanos às voltas com uma falta grave de padres. (BORRAS, 2017, p. 184).

\section{Conclusão}

Não só o Papa Francisco, mas dezenas de milhares de comunidades esperam uma resposta lúcida, corajosa e bem fundada para poderem celebrar com ministros próprios a eucaristia, "sinal da unidade" da comunidade local e da comunhão universal. Estas comunidades não querem nenhum privilégio. Querem simplesmente resgatar, com as devidas atualizações institucionais e pastorais, a prática da Igreja primitiva e antiga, onde não havia Igreja sem Eucaristia e não 
havia Eucaristia sem bispo (ou presbítero. Não se pode achar normal que na maior parte dos domingos não há eucaristia nas comunidades!

Que o Sínodo não se permita, no discernimento que será chamado a fazer desta situação, antepor o "direito de legislação" (prescrições relativas ao estado de vida dos padres e outras de instituição eclesiástica) ao "direito da graça" (no caso, o acesso à celebração da eucaristia, de instituição divina). Como ajustar estes dois legítimos direitos, quando o direito de legislação prejudica ou chego mesmo a impedir o direito da graça, senão relativizando o primeiro? O "direito da graça" ou "direito sacramental" deve prevalecer sobre o "direito de legislação" tanto em relação ao celibato como em questões menores como o tipo de formação, o exercício de profissão civil, o estilo de vida mais laical que sacral, etc.

A resposta que se der, a partir dos resultados do Sínodo para a Amazônia, para esta questão, terá certamente um impacto - que esperamos seja alvissareiro para situações semelhantes em outras áreas da Igreja, tanto no Sul como no Norte do planeta. Pesa sobre o Sínodo para a Amazônia uma grande responsabilidade, pois se depositam nele grandes esperanças. Lobinger se perguntava por onde começar ou por onde começaria esta mudança, se no Norte, se no Sul. Pensava - e fazia dez considerações! - que as Igrejas do Norte deveriam dar o primeiro passo. Esperar para ver!

A introdução do ministério presbiteral em comunidades não elimina, antes valoriza, a rica, variada e multiforme ministerialidade local e laical. Também não desvaloriza nem dispensa os presbíteros - diocesanos e religiosos - que, por sua formação e experiência, por sua entrega radical, inclusive em virtude do carisma do celibato, poderão (e deverão!) assessorar e acompanhar e contribuir para a formação dos "presbíteros comunitários", assumir responsabilidades pastorais em nível diocesano e/ou em situações mais complexas e desafiadoras. 
Lobinger insiste em que cada comunidade deve ser dotada de uma equipe de ministros ordenados. A intenção é exprimir o caráter colegial do ministério ordenado, prevenir o autoritarismo, coibir a centralização, garantir um rodízio na presidência das celebrações, etc. Em um próximo trabalho, penso retomar esta ideia, alargando-a no sentido de uma equipe de animação da comunidade formada pelo ou pelos presbíteros da comunidade local, pelo ou pelos respectivos diáconos e diáconas (que - com certeza moral - serão reintroduzidas entre os ministérios ordenados!) e por alguns leigos e leigas representativos da comunidade, eleitos por ela.

A eventual implementação desta proposta de "presbíteros de comunidade" ou "equipes de ministros ordenados" deve obedecer a uma séria pedagogia, criteriologia e metodologia. Supõe, evidentemente, Igrejas locais e comunidades convictas da necessidade e possibilidade de dar esse passo, além de pessoas preparadas e dispostas a servir seus irmãos e irmãs através do ministério presbiteral na sua comunidade. Nem toda comunidade deve ou estará em condições de ter presbíteros comunitários. Nem mesmo todas as dioceses. Talvez o caminho melhor seja o que foi pensado, "mutatis mutandis", na chamada "restauração" do diaconato permanente: aprovada pela instância competente a ordenação de homens casados (de certa maneira, é disso que se trata, uma vez que esta era a praxe mais comum no primeiro milênio), "as várias espécies de competentes grupos territoriais de bispos, com a aprovação do sumo pontífice, decidem se e onde é oportuno instituir tal tipo" (LUMEN GENTIUM 29) de presbíteros, cabendo às dioceses definir sinodalmente seu próprio caminho.

Nesta fase preparatória e na celebração do Sínodo, rezemos o "Adsumus"12: "Aqui estamos diante de vós, ó Espírito Santo Senhor nosso; aqui estamos cônscios dos nossos inúmeros pecados, porém unidos de modo particular em vosso nome.

\footnotetext{
12 Esta oração, atribuída a Isidoro de Sevilha (560-636), tem sua origem na liturgia dos concílios (sínodos) locais. No IV Concílio de Toledo (5 de dezembro de 633), convocado pelo rei e presidido por Isidoro, arcebispo, se fez, como era de praxe, uma antiga liturgia sinodal; aliás, todo o desenrolar do encontro sinodal tem um andamento litúrgico, não só jurídico e teológico. Teria sido nesta ocasião que a antiga liturgia sinodal foi enriquecida pelo Adsumus, mas há controvérsia (MONTINI, 2003, p. 164-194).
} 
Vinde a nós e ficai conosco: dignai-vos de penetrar em nossos corações. Sede guia das nossas ações, indicai-nos aonde devemos ir, e mostrai-nos o que devemos fazer, a fim de que, com o vosso auxílio, em tudo possa ser-vos agradável a nossa obra. Sede, vós só, o nosso inspirador, e dirigi as nossas intenções, pois só vós possuís um nome glorioso juntamente com o Pai e o Filho. Não permitais nunca que sejamos perturbadores da justiça, vós que sois a infinita equidade; não permitais que a ignorância nos induza ao mal, que as lisonjas nos curvem, que os interesses morais e materiais nos corrompam. Mas uni só a vós os nossos corações, fortemente, com o dom da vossa graça, a fim de que possamos ser em vós uma coisa só, e em nada nos afastemos da verdade. Assim como estamos unidos em vosso nome, possamos em cada obra nossa seguir os ditames da vossa piedade e da vossa justiça, a fim de que, hoje e sempre o nosso juízo não se aparte do vosso, e no século futuro possamos conseguir o prêmio da nossa ação. Amém”.

\section{REFERÊNCIAS}

AQUINO, Tommaso. La Somma Teologica. Terza parte. Bologna: Edizioni Studio Domenicani, 2014.

ALLMEN, J. J. Estudo sobre a ceia do Senhor. São Paulo: Duas Cidades, 1968.

ALMEIDA, A. J. Os ministérios não-ordenados na Igreja da América Latina. São Paulo: Loyola, 1989.

ALMEIDA, A. J. Igrejas locais e colegialidade episcopal. São Paulo: Paulus, 2001.

ALMEIDA, A. J. O ministério dos presbíteros-epíscopos na Igreja do Novo Testamento. São Paulo: Paulus, 2001.

ALMEIDA, A. J. Introdução à edição brasileira. Uma proposta madura à espera de uma resposta urgente. In: Lobinger, F. Padres para amanhã: uma proposta para comunidades sem Eucaristia. São Paulo: Paulus, 2. ed. 2008. p. 9-72.

ALMEIDA. A. J. Novos ministérios: a necessidade de um salto à frente. São Paulo: Paulinas, 2013.

ALMEIDA, A. J. Procuram-se padres: centralidade da Eucaristia e escassez de clero. São Paulo: Paulinas, 2018. 
BANKS, R. Ordinamento e governo della Chiesa. In: Hawthorne, G. F.; Martin, R. P.; Reid, D. G. (org.). Cinisello Balsamo (MI): San Paolo, 1999. p. 226-236.

BARbAgliO, G. As cartas de Paulo (I). São Paulo: Loyola, 1989.

BEAUDUIN, L. Essai de manuel fondamental de liturgie. Paris: QLP 3, [1912/13].

BÍBLIA DE JERUSALÉM. São Paulo: Paulus, 2002.

BORRAS, A. Quel avenir pour les prêtres? Quels prêtres pour l'avenir? Esprit et Vie, Paris, n. 51, p. 17-18, 2002.

BORRAS, A. Quand les prêtres viennent à manquer. Repères théologiques et canoniques en temps de précarité. Paris-Montréal: Médiaspaul, 2017.

CABÁSILAS, N. Expositio divinae liturgiae 27 (SC 4bis, 174-175 [= PG 150, 425426bc]).

CANOBBIO, G. Origine e senso dell'assioma "La Chiesa fa l'eucaristia e l'eucaristia fa la Chiesa"”. In: VECCHIA, Flavio Dalla; CANOBBIO, Giacomo; TONONI, Renato.

Eucaristia e chiesa. Brescia: Morcelliana, 2010. p. 211-232.

CASTILLO, J. M. A mudança mais urgente na Igreja é a renovação do clero. Instituto Humanitas UNISINOS - ADITAL, O3 de dezembro de 2017.

CASTORIADIS, C. L’institution imaginaire de la société. Paris: Seuil, 1975.

CATTANEO, E. I ministeri nella Chiesa Antica. Testi patristici dei primi tre secoli. Milano: Paoline, 1997.

CIPRIANO. Epistola 69, c. 5, n. 2.

CLEMENTE NETO, M. Vim para servir. Como ser Igreja no coração da Amazônia. Brasília: Edições CNBB, 2018.

CNBB, Discípulos e servidores da Palavra de Deus na missão da Igreja. Brasília: Edições CNBB, 2012.

CNBB, Ministério e celebração da Palavra. Brasília: Edições CNBB, 2019.

CONGAR, Y. M. J. La "Ecclesia" o la comunidade cristiana, sujeto integral de la acción litúrgica. In: STROTMANN, Th et al. La liturgia después del Vaticano II. Madrid: Taurus, 1969. p. 279-338.

CONGAR, Y. M. J. Religion et institution. In: BURKE, P. et al. Théologie d'aujourd'hui et de demain. Paris: Cerf, 1967.

CRISÓSTOMO, J. In epistulam I ad Corinthos (PG 61, 200). 
DAMASCENO, J. De fide orthodoxa (PG 94, 1154).

DIANICH, S. La chiesa mistero di comunione. Torino: Marietti, 1981.

DIANICH, S., Ecclesiologia: questioni di metodo e una proposta. Cinisello Balsamo (Milano): Paoline, 1993.

DIANICH, S.; NOCETI, S. Trattato sulla Chiesa. Brescia: Queriniana, 2002.

ESTRADA DÍAZ, J. A. (org.) 10 palabras claves sobre la Iglesia. Estella (Navarra): Editorial Verbo Divino, 2003.

FAIVRE, A. I laici nelle origini della Chiesa. Cinisello Balsamo (Milano): Paoline, 1986.

FLICHE, A.; MARTIN, V. Histoire de l'Église depuis les origines jusqu'à nos jours: l'Église primitive. Paris: Bloud \& Gay, 1946. v. 1.

FORTE, B. La Chiesa nell'eucaristia: per una teologia eucaristica alla luce del Vaticano II. Napoli: D’Auria, 1975.

FORTE, B. Igreja, ícone da Trindade: breve eclesiologia. São Paulo: Loyola, 1987.

FORTE, B. La Chiesa della Trinità: saggio sul mistero della Chiesa comunione e missione. Cinisello Balsamo (Milano): San Paolo, 1995.

FRIEDENBERG, E. Z. As ideias de Laing. São Paulo: Cultrix, 1975.

FUENTE, E. B. 100 momentos clave de la teología cristiana. Burgos: Monte Carmelo, 2010.

GANOCZY, A. Os sacramentos: estudo sobre a doutrina católica dos sacramentos. São Paulo: Loyola, 1988.

GERKEN, A. Teologia dell'eucaristia. Alba: Edizioni Paoline, 1977.

GIRARDI, L. Commento. In: NOCETI, S.; REPOLE, R. (org.). Commentario ai Documenti del Vaticano II, 1, Sacrosanctum Concilium. Inter mirifica. Bologna: EDB, 2014 .

GIRAUDO, C. Num só corpo: tratado mistagógico sobre a eucaristia. São Paulo: Loyola, 2003.

GIRAUDO, C. Eucaristia e Chiesa. In: CALABRESE, G.; GOYRET, Ph.; PIAZZA, O. F. (org.). Dizionario di ecclesiologia. Roma: Città Nuova, 2010.

GUERRA Y GOMES, M. El sacerdócio y el ministerio de la eucaristia en las primeras comunidades cristianas. Teología del Sacerdocio, v. 9, p. 41-118, 1977. 
HOFFMANN, J. Grâce et institution selon Hans Dombois: une nouvelle approche du mystère de l'Église. Revue des Sciences philosophiques et théologiques, Paris, v. 4, n. 52, p. 645-676, 1968.

CONSELHO EPISCOPAL LATINO-AMERICANO. Documento de Aparecida: texto conclusivo da V Conferência geral do episcopado latino-americano e do Caribe, 13-31 de maio de 2007. Brasília: CNBB; São Paulo: Paulinas: Paulus, 2008.

CONCÍlIO VATICANO, 2., 1962-1965. A Igreja: constituição dogmática Lumem gentium. 13. ed. Rio de Janeiro: Petrópolis, 1986.

CONCILIO ECUMÊNICO VATICANO II. Decreto Unitatis Redintegratio: sobre o ecumenismo. 3. ed. São Paulo: Paulinas, 2004.

CONCILIO VATICANO II. O ministério e a vida dos presbitérios: Decreto Presbyterorum Ordinus. 2. ed. Petrópolis: Vozes, 1966.

CONCILIO VATICANO II. Constituição pastoral do Concílio Vaticano II sobre a Igreja no mundo de hoje. São Paulo: Paulinas, 2005.

IGREJA CATÓLICA. Papa (1963-1978: Paulo VI). O celibato sacerdotal: encíclica Sacerdotalis caelibatus. Rio de Janeiro: Vozes, 1967.

IGREJA CATÓLICA. Papa (2013- : Francisco). Exortação apostólica Evangelii Gaudium do Sumo Pontífice ao episcopado, ao clero, às pessoas consagradas e aos fiéis leigos sobre o anúncio do Evangelho no mundo atual. 2. ed. São Paulo: Paulus: Edições Loyola, 2014.

ILLICH, I. Inverter as instituições. Lisboa: Moraes Editores, 1973.

JUNGMANN, J.-A., Missarum solemnia: explication génétique de la messe romaine. I. Paris: Aubier, 1951.

KLOPPENBURG, B. (org.). Compêndio do Vaticano II: constituções, decretos, declarações. Petrópolis : Vozes, 1968.

LAPASSADE, G. L'analyseur et l'analyste. Paris: Gauthier-Villars, 1971.

LEÃO MAGNO. Sermo 63 (PL 54, 357c).

LEGRAND, H. M. La présidence de l'Eucharistie selon la tradition ancienne. Spiritus, v. 18, p. 409-431, 1977.

LEGRAND, H. M. Grâce et institution dans l'Église: les fondements théologiques du droit canonique. In: LEGRAND, Hervé-Marie (dir.). L'Église: institution et foi. Bruxelles: Facultés Universitaires Saint-Louis, 1979. p.139-172.

LÉON-DUFOUR, X. O partir do pão eucarístico segundo o Novo Testamento. São Paulo: Loyola, 1984. 
LOBINGER, F. Padres para amanhã: uma proposta para comunidades sem eucaristia. São Paulo: Paulus, 2. ed. 2008.

LOBINGER, F.; ALMEIDA, A. J. Equipes de ministros ordenados: uma solução para a eucaristia nas comunidades. São Paulo: Paulus, 2009.

LOURAU, R. A análise institucional. Petrópolis: Vozes, 1975.

LUBAC, H. Cattolicismo: aspetti sociali del dogma. Milano : Jaca Book, 1978.

LUBAC, H. Corpus mysticum: l'eucarestia e la chiesa nel medioevo. Milano: Jaca Book, 1996.

MARGUERAT, D. La première histoire du christianisme: les Actes des Apôtres. Paris-Génève: Labor et Fides, 1999.

MARTINI, C. M. La cena del Signore: parola spirito e vita. Roma: Edizioni Dehoniane Bologna, 1979. (Quaderni di lettura biblica, 7).

MCPARTLAN, P. The Eucharist makes the Church: Henri de Lubac and John Zizioulas in dialogue. Edinburgh: T\&T Clark, 1993.

MONTINI, G. P. Adsumus, Domine Sancte Spiritus, adsumus. La preghiera nella sessione per la decisione giudiziale (can. 1609 § 3). Quaderni di diritto ecclesiale, v. 16, p. 164194, 2003.

MISSALE ROMANUM. 16. ed. Torino: Marietti, 1955.

MUNIER, C. Corpus christianorum. Brepols: Tournholt, 1963. (Series Latina 148 e 181).

MURATORI, L. A. Relation des missions du Paraguay. Paris: Bodelet, 1754.

NOCETI, S.; CIOLI, G.; CANOBBIO. G. (org.). Ecclesiam intelligere: studi in onore di Severino Dianich. Bologna: EDB, 2012.

PENNA, R. Le prime comunità cristiane: persone, tempi, luoghi, forme, credenze. Roma: Carocci, 2011.

PERROT, C. L' Eucaristia nel Nuovo Testamento. In: BROUARD, M. (ed.). Enciclopedia dell'Eucaristia. Bologna: EDB, 2005. p. 71-102.

PIÉ-NINOT, S. Teología fundamental. Madrid: Biblioteca de Autores Cristianos, 2016.

RAHNER, K. Wort und Eucharistie: Schriften zur Theologie. 4. ed. Eisiedeln: Benziger Verlag Eisiedeln Zürich Köln, 1960.

RAHNER, K. Chiesa e sacramenti. Brescia: Morcelliana, 1973. 
RIGHETTI, M. Manuale di storia liturgica. Milano: Ancora, 2014.

ROSMINI, A. Las cinco llagas de la Santa Iglesia: tratado dedicado al clero católico. Maracaibo: Ediciones Penínsola, 1968.

ROUTHIER, G. La Chiesa nata dalla Parola. In: BRESSAN, L.; ROUTHIER, G. L'efficacia della parola. Bologna: EDB, 2011. p. 115-129.

SÍNODO PARA A AMAZÔNIA. Novos caminhos para uma Igreja com rosto amazônico. Documento Preparatório. Brasília: Edições CNBB, 2018.

TABORDA, F. Lex orandi - Lex credendi. Origem, sentido e implicações de um axioma teológico. Perspectiva Teológica, Belo Horizonte, v. 35, p. 71-86, 2003.

TOMMASO D’AQUINO. La Somma Teologica. Bologna: Edizioni Studio Domenicano 2014 .

VICENTE DE LÉRINS. Commonitorium (PL 50, 640).

WELTE, B. Zum Verständnis der Eucharistie. Freiburg: Auf der Spur des Ewigen, 1965. p. 459-467.

AGOSTINHO. Sermo 272 [PL 38, 1247]; Sermo 234 [PL 38, 1.116].

AGOSTINHO. Sermo 234 [PL 38, 1.116]. 